\title{
TINERII ÎN BISERICĂ \\ ŞI NECESITATEA EXPLICĂRII UNOR EXPRESII \\ CULTICE UZUALE
}

Ciprian Streza*

\begin{abstract}
Young people in the Church and the necessity of explaining some particular common liturgical expressions. It is time for the current liturgical theology to meet the missionary imperative the postmodern era demands. When liturgical expressions and the whole Orthodox worship are explained, and the youth is actively engaged in the liturgical life of the Church, then the current theological discourse can become relevant to our contemporary society. The Early Church has always been aware of the necessity to uphold a living theology, which would proclaim Christ and teach Christians how to sense His unseen and mystical presence in its acts of worship, by interpreting and translating the liturgical language, so that all may understand it.
\end{abstract}

Keywords: Church, Worship, Liturgy, Tradition, Mission.

Într-o modernitate a contrastelor puternice, a dezbinărilor profunde, a relativismului individualist, a valorizării excesive a vieţii biologice, considerată ca unica formă de împlinire a existenţei umane ce se rezumă aproape exclusiv la planul material, într-o lume în care valorile spiritualităţii creştine sunt tot mai contestate, Biserica este chemată la un nou tip de pastoraţie. Discursul ei misionar trebuie să fie unul viu, dinamic, şi trebuie să se adreseze în primul rând tinerei generaţii atât de mult afectată de secularismul societăţii post moderne. În acest sens, un rol major revine lucrării pastoral-misionare a Bisericii care este chemată la o ieşire din ,captivitatea babilonică” a stereotipurilor, a limbajului sec, a rutinei şi a lipsei de relevanţă pentru realităţile contemporane.

Într-o lume consumistă în care toate valorile tradiţionale creştine sunt puse sub semnul întrebării, într-o societate care îşi

* PhD Professor, Faculty of Orthodox Theology „Sfântul Andrei Șaguna” at „Lucian Blaga” University in Sibiu. 
clădeşte tot mai mult un discurs critic, tinerii sunt tentaţi să adopte noul crez al lumii idustrializate şi excesiv urbanizată: believing without belonging ${ }^{1}$, adică descătuşarea de orice apartenenţă la vreo confesiune, şi refuzul oricărei forme de religie insituţionalizată, în favoarea făuririi unei religii proprii.

Prin toate mijloacele mass-media se urmăreşte crearea acestei noi confesiuni „neconfesionale” prin care tinerii societăţii consumiste şi ai reţelelor de socializare devin nişte indivizi anonimi care nu mai au puterea relaţionării personale, atât faţă de Dumnezeu, cât şi faţă de semeni. Creştinismul presupune tocmai această relaţionare personală şi de aceea el este din ce în ce mai mult marginalizat şi înlocuit cu o pseudoreligie, cu un „creştinism mutant”: „Viaţa religioasă, remarcă Grace Davie, ca şi multe alte trăsături ale societăţii post-industriale şi post-moderne, nu este atât de mult pe cale să dispară cât să sufere mutaţii majore, căci în mod cert căutarea sacrului va continua, dar în forme cu totul noi mult diferite decât cele ale trecutului..."2

Studii moderne de sociologie arată că ceea ce se petrece din punct de vedere religios cu tineretul în societăţile postmoderne este un fenomen unic şi cu totul nou. Tinerii, aflaţi la vârsta marilor întrebări şi căutări, sunt chemaţi prin educaţia pe care mass-media o face la o „ieşire din religie”, nu în sensul negării credinţei religioase, ci la o ieşire dintr-o lume în care credinţa este structurantă, la o evadare dintro lume a tradiţiei care este bazată pe ierarhie şi pe relaţii interpersonale.

„Ieşirea din religie reprezintă trecerea într-un univers în care religiile continuă să existe, dar în interiorul unei forme politice şi al unei ordini colective pe care nu le mai determină... Ieşirea din religie este, în adâncul ei, preschimbarea vechiului element religios în altceva decât religia ... o recompunere de ansamblu a lumii umane prin re-absorbţie, o

${ }^{1}$ Grace Davie, Religion in Britain Since 1945: Believing Without Belonging, Oxford, Basil Blackwell, 1994, p. 226.

${ }^{2}$ Ibidem, p. 198. Autoarea cărţii citează o statistică din Marea Britanie care arată că în acea ţară doar $60 \%$ din populaţie este nominal creştină, însă doar $14 \%$ s-a declarat că aparţine unui cult creştin anume (p. 143). 
retopire şi reelaborare a ceea ce a purtat în ea, milenii la rând, a chipului alterităţii ei religioase..."

Într-o astfel de situaţie dificilă şi într-un astfel de context critic, Biserica Ortodoxă este chemată să îşi afirme vocaţia ei misionară. Pentru a putea fi relevantă şi pentru a putea supravieţui într-o societate secularizată şi pluralistă, ea trebuie să îşi concentreze toată atenţia asupra pastoraţiei tinerilor. După 25 de ani de predare a religiei în şcoală, tinerii sunt tot mai puţin prezenţi în bisericile noastre. Cauzele acestei îndepărtări şi înstrăinări de tradiţia şi etosul nostru ortodox sunt multiple. Un element fundamental care ar putea însă să încline greu balanţa în favoarea unei pastoraţii de succes în rândul tinerilor este explicarea rânduielilor slujbelor ortodoxe, precum şi a expresiilor des folosite în cultul Biserici ${ }^{4}$. Rândurile ce urmează doresc să fie o adâncire şi o reanalizare a unor termeni liturgici des folosiţi în cultul ortodox, cu care intră în contact toţi tinerii care vin pentru prima dată la biserică, şi această iniţiativă să se concretizeze, pe cât posibil, în reînvierea practicii catehetice în Biserica Ortodoxă.

${ }^{3}$ Marcel Gauchet, Ieşirea din religie. Parcursul laicităţii, trad. de Mona Antohi, Bucureşti, Edit. Humanitas, 2006, p. 9.

4 A se vedea: Pr. Petre Vintilescu, Expresiunea „slujba cuvântătoare” din Liturghierul român, Bucureşti, 1939; Pr. Prof. Ene Branişte, Despre , inovaţii” in săvârşirea serviciilor divine, în „Studii Teologice”, nr. 3-4, 1953, p. 279-303; Idem, Probleme de actualitate ale Bisericiolor de azi: dezvoltare (evoluţie) şi revizuire (adaptare) în cult din punct de vedere ortodox, în „Ortodoxia”, nr. 2, 1969, p. 197-215; Pr. Prof. Dr. Nicolae Necula, Tradiție şi înnoire în slujirea liturgică, vol. III (vol. I și II, Edit. Episcopiei Dunării de Jos, Galați, 1996 și 2001), București, Edit. Institutului Biblic și de Misiune al Bisericii Ortodoxe Române, 2005. 


\section{Sensul şi semnificaţia expresiei: „SLUJBĂ CUVÂNTĂ-TOARE”

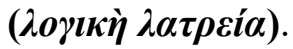

Expresia aceasta apare de trei ori în Liturghia Sfầntului Ioan Gură de Aur, o dată în textul epiclezei şi de două ori în rugăciunea dipticelor, iar în Liturghia Sfântului Vasile cel Mare ea apare în debutul anaforalei euharistice. Sintagma aceasta biblică, menţionată de către Sfântul Apostol Pavel în Epistola către Romani 12, 1:,Vă îndemn fraţilor ... să înfăţişaţi trupurile voastre ca jertfă vie, sfântă, bineplăcută lui Dumnezeu, slujirea voastră cuvântătoare...", a constituit pentru cercetarea liturgică românească obiectul unor studii consacrate ${ }^{5}$. Ambii

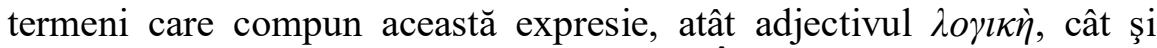
substantivul $\lambda \alpha \tau \rho \varepsilon i \alpha$ sunt polisemantici ${ }^{6}$. În limba română, $\lambda \alpha \tau \rho \varepsilon i ́ \alpha$ poate desemna un act de cult, o slujbă, fiind echivalentul cuvintelor

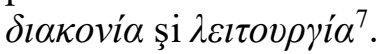

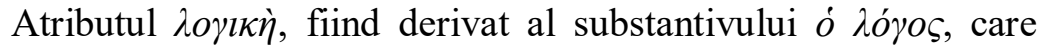
înseamnă atât „cuvânt”, cât şi „raţiune”, este asociat termenului de $\lambda \alpha \tau \rho \varepsilon i \alpha$ pentru se exprima astfel specificul cultului ortodox: slujirea care se aduce lui Dumnezeu prin Sfânta Liturghie este în acelaşi timp una „cuvântătoare”, adică se săvârşeşte prin cuvânt, prin intermediul cuvântului cântat şi rostit, dar este şi una „raţională”, ,înţelegătoare” care are loc prin participarea raţiunii, a minţii, fiind o, închinare în duh şi în adevăr”, Traducerea acestei expresii ar putea astfel fi: „slujbă duhovnicească”, cum este menţionată în ediţia Liturghierului de la

\footnotetext{
${ }^{5}$ Pr. Petre Vintilescu, Expresiunea , slujba cuvântătoare” din Liturghierul român, Bucureşti, 1939; Pr. Pavel Florensky, Slovesnie slujenie, în „Journal Moskovsckoi Patriarhii”, nr. 4, 1977, p. 63-75; Pr. Dumitru Stăniloae, Spiritualitate şi comuniune în Liturghia ortodoxă, Craiova, 1986, p. 286-297; Pr. Ene Branişte, Explicarea Sfintei Liturghii după Nicolae Cabasila, Teza de doctorat, Bucureşti, 1943, p. 150-230.

${ }^{6}$ G.W.H. Lampe, A Patristic Greek Lexikon, Oxford: At the Calderon Press, 2003, p. $793 ; 809-811$.

${ }^{7}$ Pr. Petre Vintilescu, Expresiunea ,slujba cuvântătoare”..., p. 3.

${ }^{8}$ Ibidem, p. 4.
} 
Bucureşti din 1937, sau „slujbă cuvântătoare” aşa cum apare în ediţiile actuale ale cărţilor de cult.

\section{a. Sensul expresiei „Slujbă cuvântătoare” în scrierile patristice.}

Sfinţii Părinţi ai Bisericii au preluat şi explicat această sintagmă paulină din Rom 12,1 arătând că adevărata adorare a lui Dumnezeu este cea conştientă, voită şi personală, ce are loc, atât prin cuvânt, cât şi prin praxis, prin lucrarea sfintelor porunci, prin asceză, prin întreaga orientare a fiinţei umane spre Ziditorul ei. Expresia aceasta este de 11 ori folosită de către Sfântul Vasile cel Mare în scrierile sale. ${ }^{9}$ În Regulile mici, Sfântul Vasile dă o definire unică a sensului expresiei „slujbă cuvântătoare”, spunând:

„Slujire este, după părerea mea, cinstirea angajată, continuă şi neclătinată a Celui adorat. Diferenţa dintre slujirea cuvântătoare şi cea necuvântătoare ne-o înfăţişează Apostolul spunând câte odată: Ştiţi că atunci când eraţi păgâni eraţi târâţi, ca şi cum eraţi mânaţi, iar altă dată: Să înfăţişaţi trupurile voastre ca jertfă vie, sfântă, bineplăcută lui Dumnezeu, slujirea voastră cuvântătoare. Cel care este târât ca şi cum ar fi mânat aduce slujire necuvântătoare, pentru că, pe de o parte, el nu se conduce din îndemn şi intenţie proprie sub îndrumarea raţiunii, iar pe de altă parte este dus, fără voia lui spre ceea îl duce autoritatea celui care îl târăşte. Cel care însă cu minte sănătoasă şi cu bună cugetare tinde întotdeauna şi în orice împrejurare către ceea ce place lui Dumnezeu şi săvârşeşte această, acela împlineşte porunca slujirii cuvântătoare..."'10.

${ }^{9}$ Termenul de $\lambda o \gamma \iota \kappa \grave{\eta} \lambda \alpha \tau \rho \varepsilon i \alpha$ a fost căutat în scrierile patristice cu ajutorul bazei de date: Thesaurus Linguae Graecae, CD-ROM data-base, Irvine, CA: University of California, 1992, permanent actualizată online la: http://www.tlg.uci.edu/, şi cu ajutorul motorului de căutare: http://stephanus.tlg.uci.edu/indiv/textsearch.

${ }_{10}$ Basilius Caesariensis, Asceticon magnum sive Quaestiones (regulae brevius

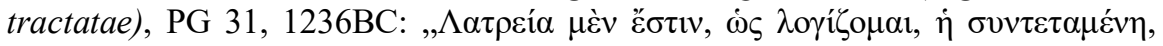

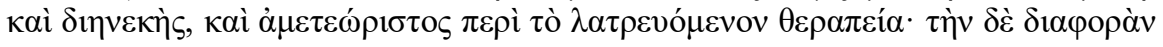

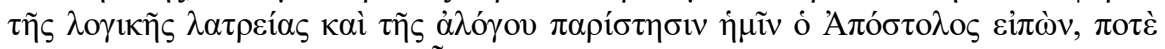

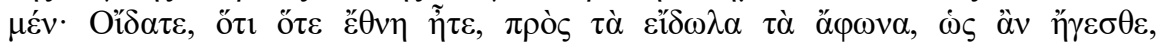

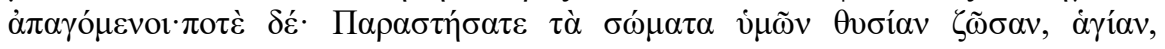


De asemenea, remarcabil este şi pasajul Comentariul la cartea Profetului Isaia, 1, 24, în care Sfântul Vasile cel Mare defineşte şi mai precis această expresie: „Ce-mi foloseşte, zice, mulţimea jertfelor voastre? Şi mulţimea [jerfelor] nu o primeşte [Dumnezeu]: o singură jertfă cere. Să se aducă fiecare însuşi pe sine lui Dumnezeu, înfăţişându-se pe sine ca jertfă vie, bineplăcută lui Dumnezeu, prin jertfă cuvântătoare, jertfind lui Dumnezeu jertfă de laudă" ${ }^{11}$.

Pentru Sfântul Grigorie de Nyssa expresia paulină din Rom 12, 1 se referă la împărtăşirea creştinilor din starea de jertfă a umanităţii curate a lui Hristos, „Care S-a adus pe Sine dar şi jertfă pentru noi şi deci prin aceasta învăţăm că şi cel care priveşte spre Acela Care S-a adus pe Sine dar şi jertfă şi S-a făcut Paştele [nostru], şi el se va înfăţişa lui Dumnezeu jertfă vie, sfântă, bineplăcută, devenind slujire cuvântătoare..." 12

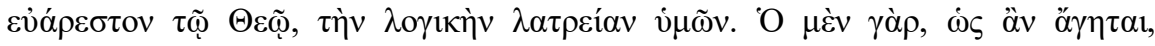

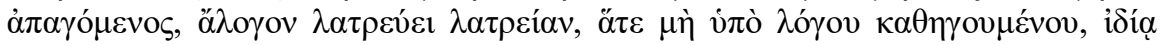

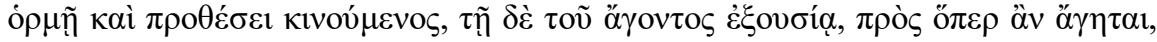

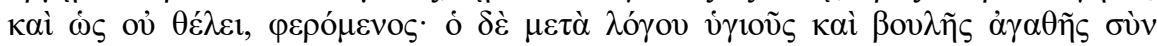

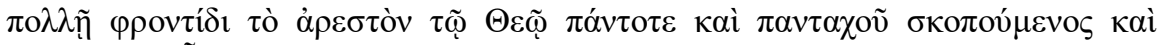

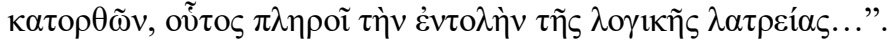

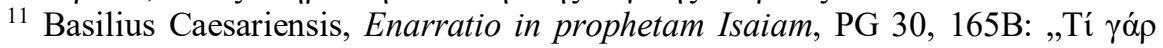

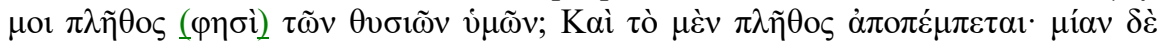

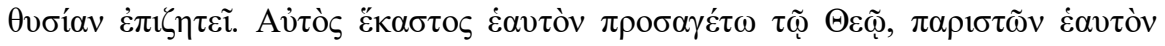

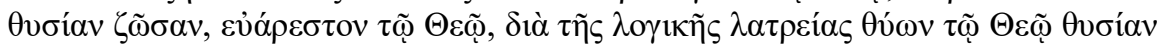

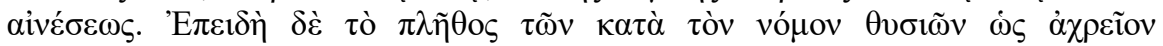

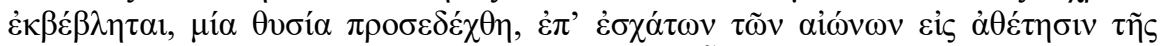

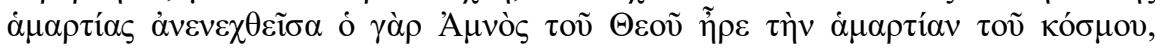

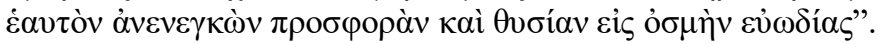

${ }^{12}$ Gregorius Nyssenus, De perfectione Christiana ad Olympium monachum, W. Jaeger, Gregorii Nysseni opera, vol. 8.1. Leiden: Brill, 1963, p. 186: „Eavtòv

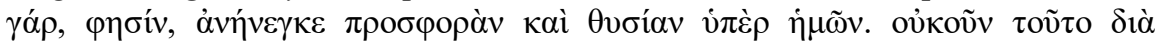

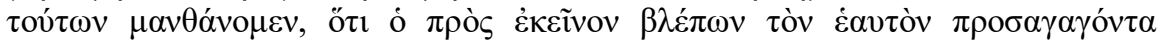

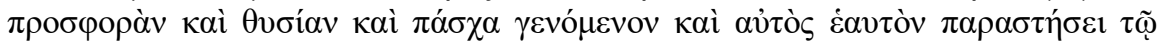

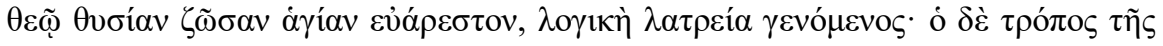

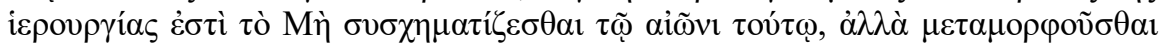


Însemnarea cu semnul cinstitei şi de viaţă făcătoarei Cruci este pentru Sfântul Ioan Gură de Aur prilej de a îndemna pe creştini la trăirea jertfei lui Hristos: „când te pecetluieşti [cu semnul Crucii], umple-ţi fruntea cu îndrăzneală [ $\pi \alpha \dot{\rho} \dot{\rho} \eta \sigma i ́ \alpha]$, iar pieptul, ochii şi toate mădularele să le înfăţiş̧ezi jertfă bineplăcută lui Dumnezeu. Acesta este slujirea cuvântătoare" 13 .

În comentariul la Epistola către Romani, acelaşi inspirat sfânt părinte defineşte sintetic ce este slujirea cuvântătoare, arătând că ea

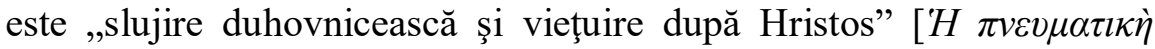

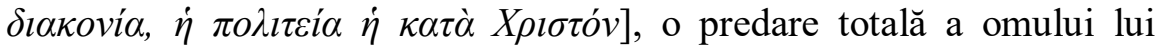
Dumnezeu, atât prin participarea la viaţa sacramentală a Bisericii, cât şi prin viaţa de asceză şi prin împlinirea poruncilor ${ }^{14}$.

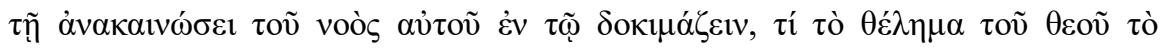

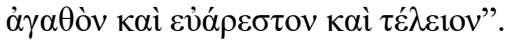

${ }^{13}$ Joannes Chrysostomus, De adoratione pretiosae crucis, PG 52, 838BC: „Oтаv

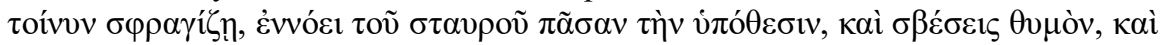

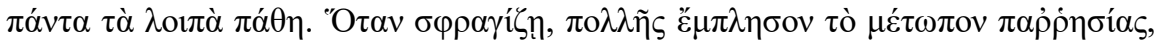

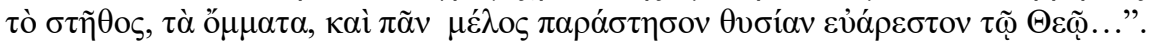
${ }^{14}$ Joannes Chrysostomus, In epistulam ad Romanos (homiliae 1-32), PG 60,

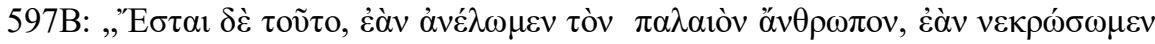

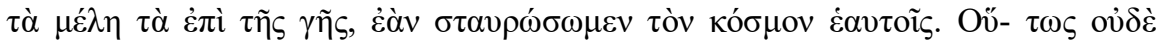

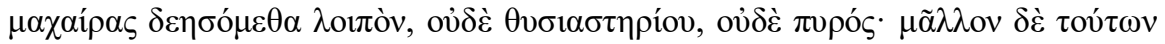

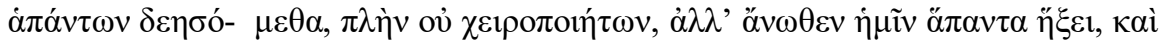

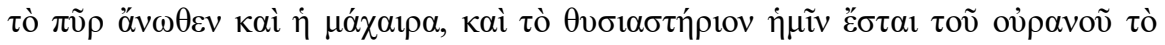

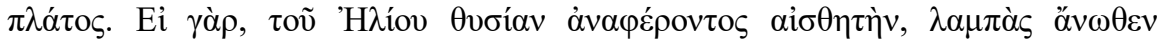

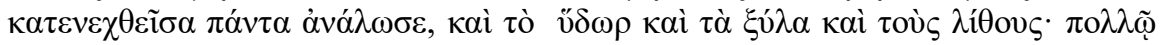

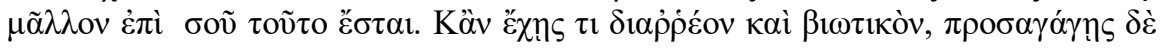

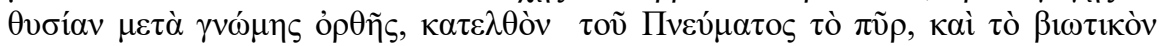

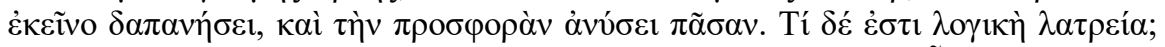

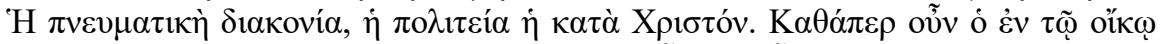

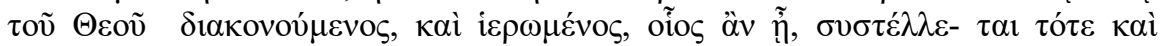

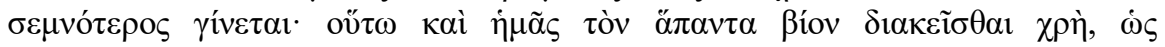

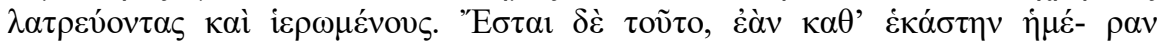

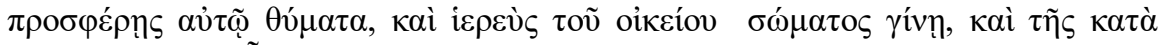

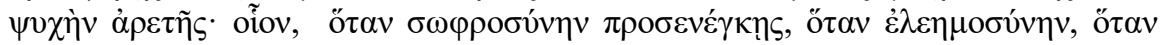

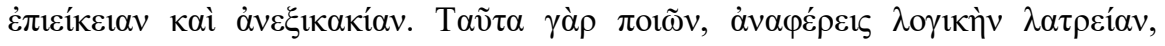

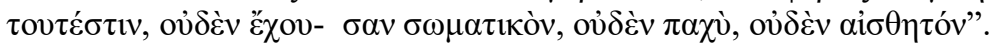


În comentariul la Epistola către Evrei tot Sfântul Ioan Gură de Aur defineşte şi mai îndeaproape această expresie arătând că ea desemnează un mod nou de vieţuire, vieţuirea în Hristos: „Ce este slujirea cuvântătoare? Toate cele făcute cu sufletul, toate cele făcute cu duhul, toate câte nu au nevoie de trup, de unelte, de locuri, precum milostivirea, înţelepciunea, facerea de bine, nerăutatea, îndelunga răbdare, smerenia..."15.

Sfântul Chiril al Alexandriei în una dintre omiliile sale pascale explică semnificaţia sintagmei pauline din Rom 12, 1, astfel: „Scris este: «înfăţişaţi trupurile voastre ca jertfă vie, sfântă, bineplăcută lui Dumnezeu, slujirea voastră cuvântătoare»... Înţelege dar că slujire cuvântătoare numeşte [Apostolul] sfinţirea omului..."16.

${ }^{15}$ Joannes Chrysostomus In epistulam ad Hebraeos (homiliae 1-34), PG 63, 92C:

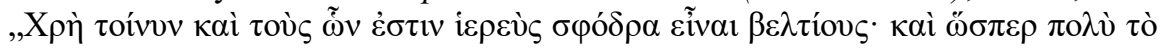

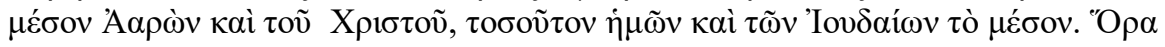

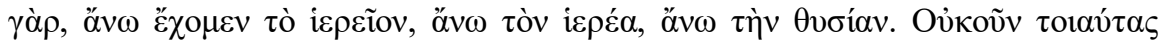

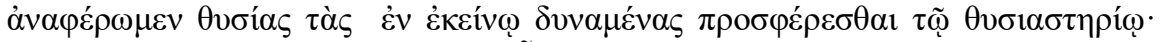

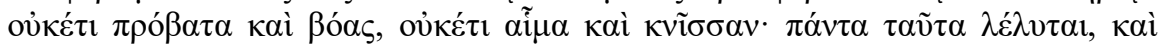

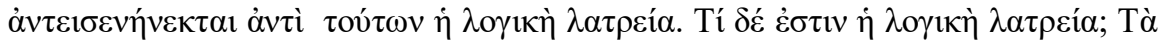

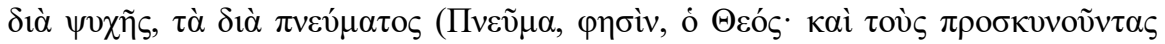

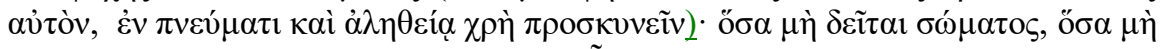

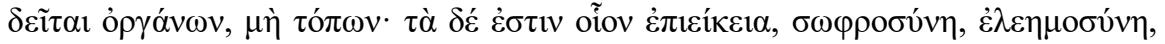

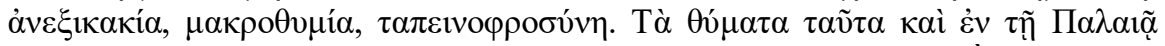

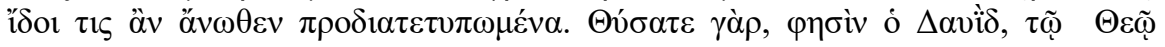

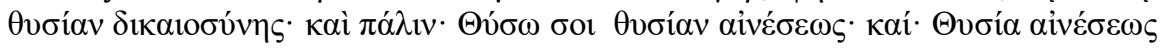

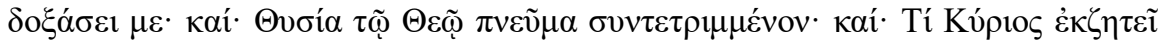

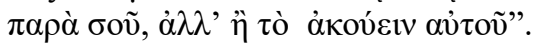

${ }^{16}$ Cyrillus Alexandrinus, Epistulae paschales sive Homiliae paschales (epist. 1-

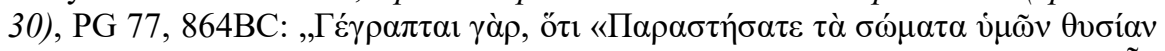

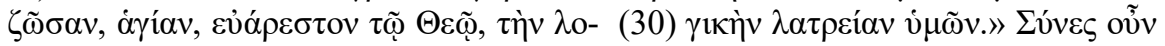

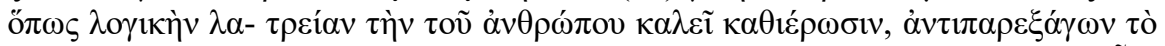

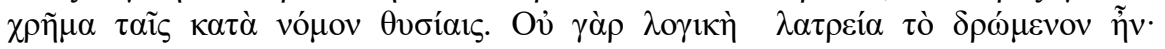

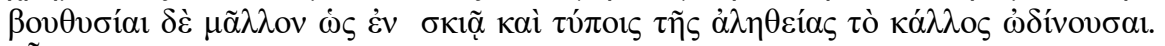

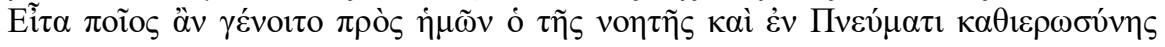

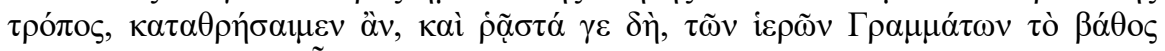

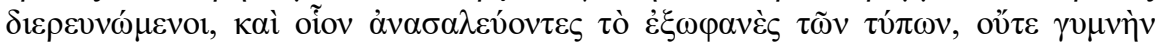

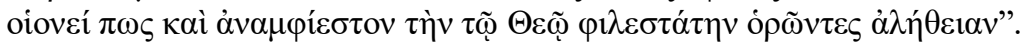


Pentru Sfântul Teolipt al Filadelfiei trăirea unei vieţi dăruită în întregime lui Dumnezeu este sensul profund al expresiei folosite de către Sfântul Apostol Pavel în Epistola sa către Romani:

„În legea veche era poruncită aducerea jertfei animalului mort, în legea harului însă [e poruncită] omorârea mădularelor trupului aplecate spre faptele patimilor şi păzirea nemişcată a puterilor sufletului spre mişcările cele stricăcioase, dispoziţia grabnică întotdeauna spre împlinirea voilor divine, aducerea pe buze cu înţelegere a imnelor dumnezeieşti şi lucrarea rugăciunii cu mintea în trezvie. Aceasta este jertfa vie şi bineplăcută şi slujba cuvântătoare"17.

Din toate aceste scurte pasaje patristice se poate vedea faptul că sintagma paulină din Rom 12,1 a fost interpretată de către Părinţii Bisericii ca fiind o referire sintetică la imperativul Evangheliei de jertfire a întregii vieţi lui Dumnezeu, de trăire a noii vieţi a lui Hristos dăruită creştinilor prin Sfintele Taine şi de împropriere a acestui nou mod de viaţă prin asceză şi prin împlinirea poruncilor. Creştinii pot face acest act de aducere, de dăruire integrală lui Dumnezeu, atât cu trupul, cât şi cu sufletul, doar primind sacramental, dar şi etic şi ascetic puterea jertfirii din umanitatea curată a lui Hristos. Astfel, pentru tradiţia patristică, omul, fiind prin excelenţă cuvânt cuvântător, creat

17 Theoleptus Philadelphiensis, Orationes monasticae 4, critical edition by R.E. Sinkewicz in: Theoleptos of Philadelphia, The Monastic Discourses [Studies and

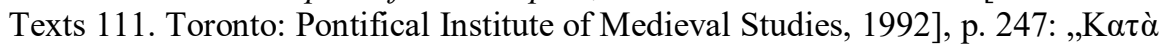

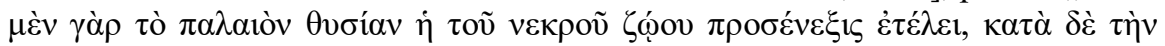

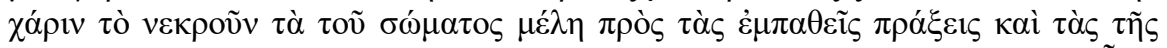

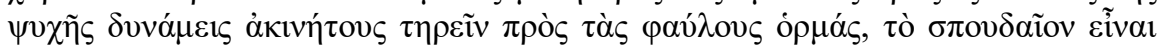

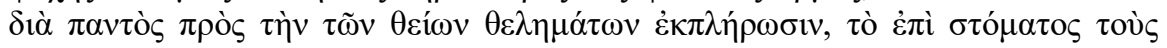

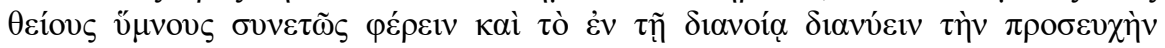

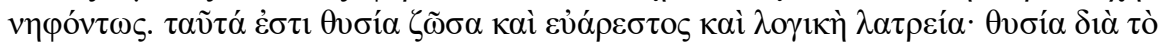

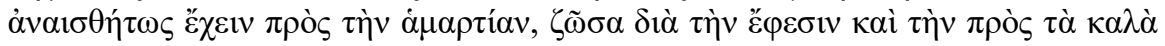

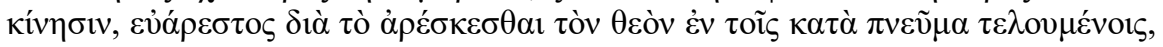

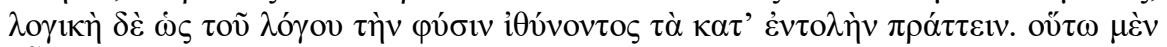

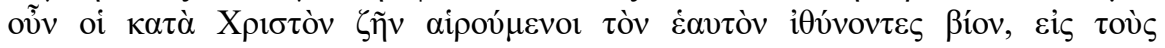

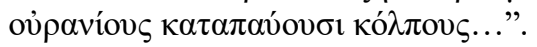


după chipul Cuvântului lui Dumnezeu, se poate menţine ca jertfă vie înţelegătoare doar prin dragostea aratată prin cuvânt şi prin faptă, doar prin dialogul viu şi personal cu Acesta, şi doar într-o dăruire totală Acestuia.

\section{b. Sensul expresiei „Slujbă cuvântătoare” în textele liturgice.}

Sensul acestei sintagme biblice este însă în tradiţia euhologică a Bisericii mult mai profund decât poate sugera simpla ei traducere gramaticală. Această expresie este asociată jertfei euharistice în anaforaua Sfântului Ioan Gură de Aur, căci la cuvintele prin care se prezintă darurile aduse pentru a fi prefăcute în Trupul şi Sângele Mântuitorului: „Ale Tale dintru ale Tale aducându-Ţi, în toate şi pentru toate pe Tine te lăudăm, pe Tine te binecuvântăm..." [Tò $\sigma \grave{\alpha} \dot{\varepsilon} \kappa \tau \tilde{\omega} v$

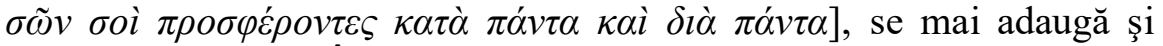
această propoziţie: „Încă aducem Ție această slujbă cuvântătoare şi fără

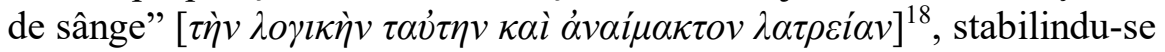
un paralelism perfect între jertfa euharistică şi jertfa de laudă pe care o aduc credincioşii, pentru a se arăta astfel că adevărata latrie sau adorare a lui Dumnezeu se face prin actualizarea jertfei instituite de către Mântuitorul la Cina cea de Taină. Referindu-se la acest pasaj prin care este introdusă epicleza în Liturghia Sfântului Ioan Gură de Aur, Părintele Dumitru Stăniloae sugerează că particula ěct trebuie tradusă de fapt cu ,încă”, dar cu sensul de ,în plus”, dând frazei următorul înţeles: „În plus îţi aducem şi darurile acestea, care prin venirea Sfântului Duh vor fi prefăcute în Jertfa lui Hristos" ${ }^{\prime 19}$, astfel încât darul credincioşilor şi răspunsul lui Dumnezeu la acest dar prin prefacerea lui devin o unică şi tainică realitate: „Comunitatea dăruieşte nu numai pâinea şi vinul, deci toate ale ei lui Dumnezeu, ci şi pe ea însăşi, pentru ca pâinea şi vinul să treacă la starea de trup şi sânge al lui Hristos. Însă ea se dăruieşte şi prin rugăciune, în măsura în care înălţăm toate ale

18 Parenti, S. / Velkovska, E., L'Eucologio Barberini Gr. 336. Seconda editione riveduta. Con traduzione in lingua italiana (=BELS 80), Roma, 2000, p. 78.

${ }^{19}$ Pr. Dumitru Stăniloae, Spiritualitate şi comuniune ..., p. 286. 
noastre, ele sunt prefăcute mai sigur în trupul şi sângele lui Hristos Cel deplin înălţat".

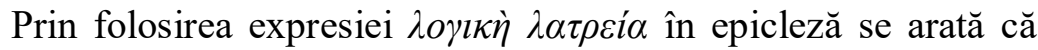
rugăciunea preotului şi a comunităţii îşi atinge în acest moment suprema eficienţă ca slujire sau ,jertfă cuvântătoare" prin unirea ei cu cererea Cuvântului întrupat, prin suprema întâlnire a slujirii cuvântătoare a omului cu slujirea cuvântătoare a Cuvântului prin Duhul Sfânt:

„Hristos cere Tatălui împreună cu preotul, spune Părintele Dumitru Stăniloae, şi cu comunitatea liturgică, rugat de aceştia, prefacerea pâinii şi vinului prin Duhul în trupul şi sângele Său, dar o şi lucrează aceasta pentru a le oferi pe de o parte Tatălui pentru ei, pe de altă parte pentru a le întoarce lor prefãcute astfel, pentru că darurile acestea au devenit ale Lui la cuvintele: «Ale Tale dintru ale Tale, Ţie Ți-aducem de toate şi pentru toate». Dar comunitatea I le-a dăruit prin preot cu scopul ca El să şi le asimileze complet şi să le înapoieze ca Trupul şi Sângele Lui, după ce lea oferit El Însuşi Tatălui şi prin cererea şi lucrarea cerută de preot şi de comunitate a înfăptuit prefacerea lor prin Duhul. Cererea Lui către Tatăl e totodată lucrare, dar lucrare nu numai a celui ce cere, ci şi a Celui de la care se cere. Deci într-un anumit fel Hristos se interesează mai departe de darurile ce I le-a adus comunitatea. Ele sunt oarecum comune comunităţii şi lui Hristos. Rugat de comunitate, El cere Tatălui, împreună cu comunitatea să le prefacă prin Duhul Sfầnt în Trupul şi Sângele Lui - şi prin aceasta El Însuşi contribuie la prefacerea lor - pentru a le preda ca jertfă a Sa şi ca darul comunităţii, Tatălui, dar şi pentru a le întoarce ei" ${ }^{\prime 20}$

Dacă în literatura patristică sintagma din Rom 12, 1 se referă la jertfirea totală, atât cu sufletul, cât şi cu trupul, pe care omul trebuie să o aducă lui Dumnezeu, în textele euhologice ale anaforalelor euharistice bizantine, acest sens este adâncit prin raportarea lui la Jertfa lui Hristos, indicându-se astfel că împlinirea existenţei umane constă în perpetua dăruire a ei lui Dumnezeu, din şi cu puterea Jertfei Mântuitorului. Jertfã cuvântătoare este necontenitul schimb de daruri

${ }^{20}$ Ibidem, p. 292. 
dintre Dumnezeu şi om, ce are loc în fiecare Sfântă Liturghie. Creştinii îşi aduc propriile lor vieţi ofrandă Ziditorului împreună cu Ofranda cea mare pe care Hristos o aduce necontenit în cer Tatălui. Această aducere se face prin raţiune şi prin cuvântul buzelor, care e rugăciunea, ca jertfă şi ca izvor al întregii jertfelnicii.

„Predarea întregii noastre vieţi lui Hristos, constituie epicleza continuă, interioară, cu fapta, a harului Sfầntului Duh, afirmă Părintele Dumitru Stăniloae. În momentul epiclezei aducerea tuturor celor ale noastre Lui, pentru toate atrage harul; ea constituie rugăciunea, cererea şi implorarea adresată Tatălui de a trimite Duhul Sfầnt"21.

Astfel, epicleza nu e o simplă rostire de cuvinte, ci este o invocare şi o cerere cu o efícienţă maximă, căci în ea se întâmplă o supremă întâlnire a slujirii cuvântătoare a omului, ca dăruire totală a sa lui Dumnezeu, cu slujirea cuvântătoare a Cuvântului prin Duhul, ca izvor al întregii jertfelnicii.

„Fiind într-o continuă stare de jertfă pentru noi Hristos «coboară» în Liturghie la noi în stare de jertfă întrucât, la cererea noastră şi a Lui, Tatăl preface prin Duhul, pentru noi, pâinea şi vinul în Trupul şi Sângele Său jertfit pentru a ne urca şi pe noi cei ce ne împărtăşim de El, acolo unde este El. E un act de iubire înnoit faţă de noi, dar şi faţă de Tatăl împreună cu noi, făcut pentru noi"22.

Jertfă cuvântătoare este întreaga Liturghie, căci doar prin Jertfa euharistică se încheie circuitul real şi ontologic al dialogului de dragoste între Dumnezeu şi om, între Tatăl, Fiul şi noi, prin jertfa Fiului Său. Sintagma paulină exprimă sintetic întreaga dinamică a acestui dialog de iubire desăvârşită ce se arată prin jertfă, căci „doar prin jertfa Fiului lui Dumnezeu ne putem preda Tatălui, părăsind trăsăturile egoismului nostru, unindu-ne în ea cu Fiul; prin împărtăşirea cu ea ni se dă mai deplin Fiul, cu dragostea Lui faţă de Tatăl şi de noi

${ }^{21}$ Ibidem, p. 293.
${ }^{22}$ Ibidem, p. 295. 
ca să putem relua la alte Liturghii, la o treaptă mai înaltă, această reciprocă dăruire.."23.

\section{Semnificaţia termenului de „anafora euharistică” şi explicarea structurii şi originii părţilor canonului euharistic}

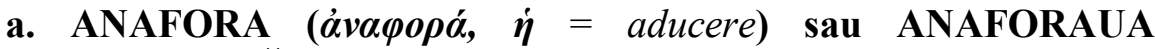
EUHARISTICĂ este termenul care a desemnat iniţial întreaga celebrare euharistică a primilor creştini şi abia începând din secolul VI el a ajuns să definească strict Marea Rugăciune a Sfintei Jertfe din rânduiala Sfintei Liturghii, în cursul căreia avea loc prefacerea Darurilor. Substantivul $\dot{\eta} \dot{\alpha} v \alpha \varphi \rho \rho \dot{\alpha}$ provine de la verbul $\dot{\alpha} v \alpha \varphi \dot{\varepsilon} \rho \omega$ care înseamnă a înălţa, a ridica, a oferi ${ }^{24}$. În limbajul biblic vechi

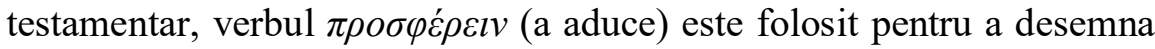

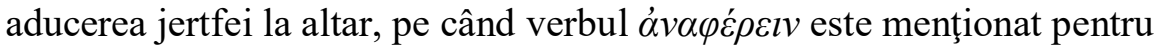
a marca actul de ridicare, de oferire a jertfei pe altar (Lev 2, 14; 2, 16; $3,1-5)$. Cele două sensuri au fost apoi preluate şi de terminologia creştină, astfel încât prin „anafora” s-a definit nucleul Liturghiei creştine care conţinea, atât actul de aducere, cât şi pe cel de înălţare, ridicare şi sfinţ̧ire a darurilor, accentuându-se însă nuanţa pregnantă şi sensul de jertfă şi de ofrandă a acestui termen ${ }^{25}$.

În rânduiala Liturghiei ortodoxe, prin Anafora euharistică se înţelege tot şirul de rituri şi rugăciuni citite de către preot (cele mai multe în taină) cuprinse de la ecfonisul preotului: „Să stăm bine să stăm cu frică, sfânta jertfă (anafora) cu pace să o aducem...”, până la: ,Şi ne dă nouă cu o gură şi o inimă a mări şi a cânta...", adică de la rostirea Crezului şi până la rugăciunea „Tatăl nostru”.

\section{${ }^{23}$ Ibidem, p. 297.}

${ }^{24}$ Henry George E. Liddell, \& Robert Scott, A Greek-English Lexicon (revised ed.), Oxford: At Clarendon Press, 1996, p. 125; Lampe, G.W.H., A Patristic Greek Lexikon, Oxford: At the Clarendon Press, 2003, p. 127-128.

${ }^{25}$ G.W.H. Lampe, A Patristic Greek Lexikon, Oxford: At the Clarendon Press, 2003, p. 127-128. 
Adresată lui Dumnezeu Tatăl, anaforaua cuprinde în textul ei toate actele făcute de către Mântuitorul înainte de patima Sa, când, săvârşind o cină frăţească specifică (havuroth), El a luat pâinea (1), a binecuvântat-o (2), a frânt-o (3), şi a dat-o (4); apoi a luat paharul (5), a mulţumit (6) şi 1-a dat ucenicilor (7). Ceea ce a făcut Mântuitorul la Cina cea de Taină nu a fost decât investirea cu o nouă semnificaţie şi umplerea cu o nouă realitate legate de moartea şi Învierea Sa, a două acte ale liturghiei familiale iudaice, acte de care El era sigur că ucenicii le vor face cu regularitate şi după Înălţarea $\mathrm{Sa}$, căci ele aparţineau existenţei lor cotidiene. Săvârşind aceste acte, Mântuitorul le-a însoţit $\mathrm{cu}$ formulele euhologice consacrate ale cinei iudaice, cum ar fi mulţumirea după cină (birkat ha-mazon), la care El a adăugat propriile Sale cuvinte (Acesta este Trupul Meu... şi Acesta este sângele Meu...), pentru a arăta sensul nou şi unic al celor săvârşite: prevestirea sau anticiparea sacramentală a jertfei sângeroase şi mântuitoare, care se va consuma peste o zi, şi care va inaugura sau consfinţi un nou legământ sau testament între Dumnezeu şi oameni, pecetluit cu sângele sfânt al Celui ce Se va da spre răstignire.

Biserica a continuat ceea ce Mântuitorul a fãcut la Cina cea de Taină. Cele şapte acte au fost preluate de către Biserica primară şi au fost restrânse la patru şi anume: 1. Aducerea: pâinea şi vinul erau „luate” şi aduse la altar; 2. Rugăciunea: proestosul aducea mulţumire lui Dumnezeu şi prin invocarea Sfântului Duh darurile erau transformate în Trupul şi Sângele Domnului; 3. Frângerea: pâinea era frântă şi împărţită; 4. Împărtăşirea. „În această formă şi în această ordine, aceste patru acţiuni constituie nucleul absolut invariabil al fiecărui rit euharistic, cunoscut nouă, afirmă Gregory Dix"26. Aceste acte care fundamentează orice celebrare euharistică au fost de la bun început însă însoțite de cuvinte, de anumite formule euhologice care până în secolul al IV-lea au fost caracterizate de oralitate şi improvizare $^{27}$.

${ }^{26}$ Gregory Dix, The Shape of Liturgy, Londra, 1945, p. 48.

${ }^{27}$ A. Bouley, From Freedom to Formula, Washington, D.C., 1981, p. 53-217. 
Faptul că la Cina de Taină Domnul Iisus a schimbat rugăciunile şi binecuvântările cultice iudaice şi a folosit propriile Sale cuvinte pentru a da textelor euhologice un conţinut şi un sens $\operatorname{nou}^{28}$, a dat posibilitatea ca în epoca primară, urmând acest model, episcopul să aibă o anumită libertate de a improviza şi a-şi compune anaforaua proprie, iar diversitatea de grupuri etnice din care se constituia Biserică a făcut ca în primele secole modelele de urmat în celebrarea euharistică să fie variate şi diverse. Astfel, nu au putut exista „originale“ ale vreunei rugăciuni folosite în cultul creştin primar, ci au existat dintru început o varietate de tradiţii orale, care mai târziu au fost supuse standardizării treptate.

Procesul acesta de uniformizare şi de stabilizare va fi luat sfârşit abia în secolul IV al erei creştine, când a fost fixat în scris conţinutul textelor euhologice. Astfel, anaforaua Bisericii primare a cunoscut un proces de evoluţie de la diversitate spre unitate, în sens invers decât cel conceput de Ferdinand Probst la sfârşitul secolului $\mathrm{XIX}^{29}$. Procesul de omogenizare şi de fixare în scris a început odată cu luptele antieretice ale secolului IV, şi a exprimat dorinţa de coeziune şi de unitate dogmatică şi liturgică a Bisericii. Anaforaua metropolei s-a impus, numeroasele tradiţii locale au fost înlocuite de către altele, parţial sau total, şi au supravieţuit doar anaforalele cele mai cunoscute şi cele impuse de către uzanţa metropolei ${ }^{30}$.

Structura anaforalelor euharistice este aproape identică în toate riturile liturgice, diferenţa între ele dându-o doar poziţionarea dipticelor

\footnotetext{
${ }^{28}$ B. Spinks, Beware the Liturgical Horses! An English Interjection on Anaphoral Evolution, Worship 59, 1985, p. 211-219.

${ }^{29}$ Ferdinand Probst, Liturgie der drei ersten christlichen Jahrhunderte, Tübingen, 1870 , p. 45.

30 Paul Bradshaw, The Homogenization of Christian Liturgy - Ancient and Modern: Presidential Address, Studia Liturgica 26, 1996, p. 1-6; Robert Taft, How Liturgies Grow: The Evolution of the Byzantine Divine Liturgy, Orientalia Christiana Periodica 43, 1977, p. 355-378.
} 
în întregul textului euharistic ${ }^{31}$. Anaforaua bizantină a Sfântului Ioan Gură de Aur, cea a Sfântului Vasile cel Mare şi cea a Sfântului Iacob, fratele Domnului, fac parte din familia de liturghii antiohiene şi se deschid printr-un dialog introductiv, urmat de o Rugăciune teologică prin care se exprimă lauda şi mulţumirea aduse Tatălui pentru întreaga creaţie şi pentru împlinirea iconomiei mântuirii. Faptul că Liturghia adevărată se petrece în cer, iar oamenii participă la ea împreună cu îngerii în ritualul euharistic văzut, este sugerat de cântarea Trisaghionului biblic care urmează şi care introduce apoi Rugăciunea hristologică în care se reiterează întreaga istorie a mântuirii neamului omenesc, naraţiune care se încheie cu amintirea Cinei de Taină şi a Cuvintelor de instituire.

Urmează apoi rugăciunea aducerii aminte sau Anamneza: „Aceasta să o faceţi întru pomenirea Mea” (se aminteşte împlinirea poruncii Mântuitorului) în care sunt enumerate sintetic principalele momente ale drumului jertfei şi mântuirii: „Aducându-ne aminte aşadar de toate cele ce s-au făcut pentru noi: de cruce, de groapă, de învierea cea de a treia zi, de suirea la ceruri ... şi cea de a doua slăvită iarăşi

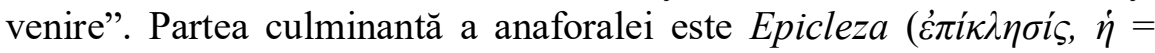
invocare, chemare), rugăciunea cea mai importantă a Liturghiei, pentru că prin ea se săvârşeşte sfinţirea şi prefacerea Darurilor. Preotul se roagă în taină ca Tatăl să trimită Sfântul Duh peste comunitate şi peste pâine şi vin pentru ca ele să se prefacă în Trupul şi Sângele Mântuitorului, împlinindu-se astfel scopul Sfintei Liturghii, şi anume: sfinţirea darurilor în vederea sfinţirii credincioşilor ${ }^{32}$.

Conform ritualului bizantin, după epicleză urmează Dipticele, rugăciunile de mijlocire generală pentru întreaga Biserică, pentru toate categoriile de credincioşi, vii şi morţi. În diptice este şi formula de

${ }^{31}$ Pr. Vintilescu, Petre, Liturghierul explicat, Bucureşti, 1972, p. 227-276; Idem, Anaforaua sau ritul Sfintei Jertfe euharistice, în „Biserica Ortodoxă Română”, nr. 7-8, 1961, p. 733-754.

32 Nicolae Cabasila, Explicarea Sfintei Liturghii, PG 150, 368-492, traducere românească la Pr. Prof. Dr. Ene Branişte, Explicarea Sfintei Liturghii, Bucureşti, 1943, p. 27. 
rugăciune pentru Fecioara Maria: „Mai ales pentru Preasfânta...” La strană începe să se cânte Axionul, iar preotul continuă să pomenească pe vii şi pe adormiţi. O Doxologie finală încheie anaforaua euharistică, ea fiind cântată cu voce tare pentru ca poporul să poate să răspundă cu „Amin!” arătându-şi astfel participarea la întregul act de aducere şi sfinţire a darurilor din cadrul Sfintei Liturghii.

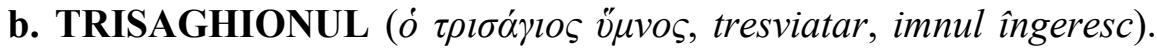
Acest termen desemnează în cultul ortodox, atât imnul liturgic „Sfinte Dumnezeule, Sfinte tare, Sfinte fără de moarte, miluieşte-ne pre noi”, care se cântă după ieşirea cu Evanghelia (vohodul mic) înainte de citirea Apostolului, cât şi cântarea îngerească: „Sfầnt, sfânt, sfầnt, Domul Savaot..." din Isaia 6, 3-6, ce a fost preluată în creşinism şi introdusă în anaforaua euharistică între Rugăciunea teologică şi cea hristologică.

Trisaghionul liturgic („,Sfinte Dumnezeule...”) a fost introdus şi generalizat oficial în rânduiala Liturghiei, între anii 450-453, în vremea lui Proclu, patriarhul Constantinopolului, şi a împăraţilor Teodosie II şi Pulcheria. Acest imn e menţionat prima dată în actele Sinodului IV ecumenic de la Calcedon, şi poate fi găsit în prezent în liturghiile bizantine, dar şi în Liturghia de rit galican (Franţa), la monofiziţi (armeni, sirieni, iacobiţi, etiopieni) şi la copţi (Egipt) care-1 cântă cu adaosul: „Cela ce Te-ai răstignit pentru noi” ${ }^{33}$.

Introducerea Trisaghionului biblic (,Sfânt, Sfầnt, Sfầnt..”) în anaforaua euharistică reprezintă o dilemă încă nerezolvată pentru cercetarea liturgică actuală. În marea majoritate a vechilor anaforale euharistice acest imn apare în rugăciunea de mulţumire pentru împlinirea iconomiei mântuirii, însă în unele texte euhologice străvechi precum: Didahia celor 12 Apostoli $^{34}$, Tradiţia Apostolică a lui Ipolit ${ }^{35}$,

${ }^{33}$ Pr. Prof. Ene Branişte, Liturgica Specială, manual pentru Institutele Teologice, Bucureşti, 1980, p. 478.

${ }^{34}$ Anton Hänggi, Irmgard Pahl (eds), Prex Eucharistica, Fribourg, 1968, p. 66-67. ${ }^{35}$ Ibidem, p. 80-81. 
Testamentum Domini ${ }^{36}$ şi anaforaua Sfầntului Epifanie al Salaminei, el lipseşte cu desăvârşire ${ }^{37}$. Primii creştini au fost în mod cert familiarizaţi cu Trisaghionul biblic din Isaia 6, 3, pentru că acest fragment biblic a fost folosit în cultul sinagogal.

Qedussah sau Trisaghionul biblic apare în cultul sinagogal iudaic în prima binecuvântarea a dimineţii Yotser $\mathrm{Or}(\mathrm{Tu}, \mathrm{Cel}$ care ai făcut lumina) care prefaţează citirea Shemei Israel ${ }^{38}$, în cea de a treia cerere a Shemon Esreh sau Tefillah sau rugăciunea celor 18 cereri $^{39}$, şi în Qedussah de Sidra, în binecuvântarea de la sfârş̧itul rugăciunii dimineţii. Mărturii despre uzul Sanctusului în Biserica primară apar în prima Epistolă a Sfântului Clement Romanu ${ }^{40}$, în relatarea martirajului Sfintelor Perpetua şi Felicitas ${ }^{41}$, în De oratione a lui Tertulian ${ }^{42}$, în actele apocrife ale lui Ioan fiul lui Zevedeu ${ }^{43}$ şi în actele apocrife ale lui $\mathrm{Toma}^{44}$. Referiri clare ale folosirii Sanctusului în cadrul anaforalei euharistice pot fi găsite şi în Istoria bisericească a lui Eusebiu de Cezareea (cartea a X-a) $)^{45}$, în Catehezele mistagogice (Cateheza 5, 6) ale Sfântului Chiril al Ierusalimului ${ }^{46}$, în anaforaua lui Serapion de Thmuis $^{47}$ şi în Constituţiile Apostolice VIII 12, $27^{48}$. În secolul al Vlea, Sanctusul era deja o componentă structurală a anaforalei

\section{${ }^{36}$ Ibidem, p. 219.}

${ }^{37}$ Robert Taft, The Interpolation of the Sanctus into the Anaphora: When and Where? A Review of the Dossier, I, OCP 57, 1991, p. 304-306.

${ }^{38}$ Anton Hänggi, Irmgard Pahl (eds), Prex Eucharistica, p. 37.

${ }^{39}$ Ibidem, p. 41-54.

${ }^{40}$ A. Jaubert, Clément de Rome. Epitre aux Corinthiens (=SC 167), Paris, 1971, p. 155-156.

${ }^{41}$ C. van Beek (ed.), Passio ss Perpetuae et Felicitatis, Nijmegen, 1936, p. 32.

${ }^{42}$ E. Dekkers (ed.), Tertulliani Opera I (=CCSL I), Turnhout, 1954, p. 259.

${ }^{43}$ Anton Hänggi, Irmgard Pahl (eds), Prex Eucharistica ..., p. 74-75.

${ }^{44}$ Ibidem, p. 76-79.

${ }^{45}$ Eusébe de Césarée, Histoire ecclésiastique, ed. G. Bardy (=SC 55), Paris, 1958, p. 81-104.

${ }^{46}$ Cyrille de Jérusalem, Catéchèses mystagogiques, ed. A. Piédagnel (=SC 16 bis), Paris, 1966, p. 154.

${ }^{47}$ Anton Hänggi, Irmgard Pahl (eds), Prex Eucharistica ..., p. 128-133.

${ }^{48}$ Ibidem, p. 82-95. 
euharistice, atât în Răsărit, cât şi în Apus, despărţind rugăciunea teologică de cea hristologică. Sunt cunoscute două forme sau tipuri de Sanctus, care corespund celor două mari tradiţii liturgice, cea egipteană şi cea antiohiană sau siriană. Identificarea acestor două tipuri de Sanctus, distincte, a dus la apariţia în cercetarea liturgică a două mari teorii privind originea şi evoluţia Trisaghionului biblic în textul anaforalei euharistice.

Prima teorie, cea egipteană, a fost făcută cunoscută de către Gregory Dix, şi postula ca origine a introducerii Trisaghionului biblic în anaforaua euharistică a fi tradiţia cultică a Alexandriei, unde se pare că a fost folosit pentru prima dată pe la mijlocul secolului al III-lea, fapt menţionat de scrierile De principiis I şi IV ale lui Origen. Această teorie a fost mai apoi nuanţată de către Georg Kretschmar care a afirmat că, în timpul lui Origen, Sanctusul nu a fost folosit în anafora, dar el a fost introdus în secolul al III-lea în textul euharistic sub influenţa teologiei marelui învăţat alexandrin ${ }^{49}$. A doua teorie a fost prezentată de către Eric C. Ratcliff într-un eseu important din 1950, în care autorul a pornit de la premisa că în mediul cultic siriac a fost pentru prima dată înserat Sanctusul în anaforaua euharistică. ${ }^{50}$ În opinia acestuia, Rugăciunea teologică a fost la începuturi o anafora în sine, căreia foarte devreme i-a fost adăugat Trisaghionul biblic, ca o concluzie a textului euharistic.

Majoritatea liturgiştilor consideră că Trisaghionul biblic ar fi o adăugire făcută textului anaforalei euharistice în secolele III-IV. Cu toate acestea, însă, în unele texte euhologice, Sanctusul pare a fi o parte componentă a nucleului originar, ceea ce duce la presupunerea că iniţial, datorită rolului mare pe care improvizația 1-a jucat în cultul primelor veacuri, a existat o varietate de „modele” de texte euharistice şi nu doar un singur arhetip originar din care au derivat toate Liturghiile cunoscute astăzi. Aceasta este şi explicaţia de ce nu toate vechile

49 G. Kretschmar, Die frühe Geschichte Jerusalemer Liturgie, Jahrbuch für Liturgik und Hymnologie 2, 1956, p. 24-28.

${ }^{50}$ E. C. Ratcliff, The Sanctus and the Pattern of the Early Anaphora, Journal of Ecclesiastical History 1, 1950, p. 29-36, 125-134. 
Liturghii cunoscute conţin Trisaghionul biblic. Anaforalele fără Sanctus, precum Tradiţia apostolică a lui Ipolit şi Testamentum Domini sunt mărturii ale unor vechi tradiţii liturgice în care Sanctusul nu a fost introdus.

Improvizaţia şi caracterul oral al cultului creştin al primelor veacuri a făcut ca şi anaforalele care conţin Trisaghionul biblic să fie diferite între ele, reflectând în esenţă două mari tipuri sau tradiții: cea egipteană şi cea siriană. În Egipt, Sanctusul nu conţine binecuvântarea finală (Benedictus) şi este perfect încadrat în structura pleni/vere plenum/imple a textului euharistic, aşa cum apare ea în Liturghia Sfântului Marcu şi în cea a lui Serapion de Thmuis. Acest fapt militează pentru o posibilă dată timpurie a adoptării Sanctusului în tradiţia liturgică egipteană, în vremea fixării în scris a textului euharistic. $\mathrm{Cu}$ toate că nu poate demonstra acest lucru, Robert Taft este de părere că Sanctusul a fost introdus în Egipt pentru prima dată în textul euharistic, iar ideea introducerii lui în Liturghia altor provincii, ar proveni tot din tradiţia cultică egipteană. În Siria, mai precis în partea ei de răsărit, cultul creştin a fost dintru început mult influenţat de cel iudaic. Astfel se explică şi faptul că cea mai veche atestare (certă!) a folosirii Sanctusului în textul euharistic apare în anaforaua siriacă a Sfinţilor Apostoli Addai şi Marji, ce a fost datată ca provenind din secolul III, având însă rădăcini ce coboară până în secolul II. Sanctusul acestui formular euhologic nu conţine binecuvântarea finală, după cum şi în tradiţia cultică iudaică Trisaghionul poate să apară şi cu, dar şi fără Benedictus.

Deşi nu există un consens în definirea originii Sanctusului în anafora, totuşi trebuie subliniat faptul că în mod cert contextul cultic iudaic în care a apărut şi s-a dezvoltat creştinismul primar a lăsat urme în tradiţia liturgică a Bisericii primelor veacuri. Elemente din cultul sinagogal au fost preluate, au fost prelucrate şi adaptate la noua realitate eshatologică a cultului creştin, însă comunităţile primare nu sau simţit obligate de a adopta sau a folosi aceste formulare euhologice iudaice, dovadă fiind modul diferit în care în fiecare regiune au fost 
receptate, adoptate şi folosite aceste elemente ale cultului iudaic, ceea ce explică şi diversitatea dintru început a anaforalelor euharistice.

Un astfel de element preluat de către Biserica primară a fost şi Trisaghionul biblic (Qedussa) ce foarte devreme a pătruns în Liturghia creştină, cu sau fără Benedictus. Tradiţia liturgică locală a fiecărei regiuni a dictat modul în care a fost integrat sau nu Trisaghionul biblic în textul euharistic creştin. În unele regiuni, precum Egiptul şi Siria, el a fost foarte devreme acceptat, devenind parte componentă a textului euharistic, în altele, însă, Trisaghionul a fost introdus mai târziu în secţiunea de mulţumire a anaforalei euharistice. Doar astfel pot fi explicate cele două mari tipuri de Sanctus ce apar în textele euhologice cunoscute până în prezent.

Trisaghionul biblic a cunoscut o evoluţie în decursul timpului. La origini, el a fost adresat lui Dumnezeu Tatăl, ca şi întregul text al anaforalei. Toate celelalte accente trinitare sau hristologice aduse lui sunt adăugiri făcute mai târziu. În mijlocul secolului IV polemica antiariană a dus mai întâi în Egipt, iar mai apoi şi în celelalte provincii ale Răsăritului ortodox, la o interpretare trinitară a Sanctusului. În Antiohia, însă şi în zonele ei de influenţă, precum Capadocia, a avut loc o interpretare hristologică a Sanctusului, ce a adus cu sine şi înlocuirea în Benedictus a pasajului din Iez. 3, 12 cu cel din Mt. 21, 9.

c. CUVINTEle DE INSTITUIRE. Naraţiunea cuvintelor de instituire, prin care Mântuitorul a întemeiat noua realitate a prezenţei Sale euharistice în Biserică, este elementul pe care se fundamentează toate actele cultice ale Sfintei Liturghii. Ea conţine nucleul originar al Sinaxei euharistice, aşa cum a fost ea săvârşită de către Hristos la Cina cea de Taină, şi mai apoi de către Sfinţii Apostoli şi urmaşii acestora. Din acest nucleu originar au crescut şi s-au dezvoltat toate Liturghiile cunoscute până în prezent ${ }^{51}$.

Cercetările biblice şi liturgice din ultimele decenii au demonstrat, pe baza analizei referatelor biblice din I. Cor. 11, 23-25 (probabil cel mai vechi dintre ele, datat fiind în jurul anului 53 d.Hr),

${ }^{51}$ Pr. Prof. Dr. Branişte, Ene, Liturgica specială..., p. 174. 
Mc. 14, 22-25; Mt. 26, 15-20; Lc. 22, 15-20, că la Cina cea de Taină, instituind Euharistia, Hristos a împlinit un rit iudaic preexistent, sacramentalizând obiceiul iudaic străvechi al meselor festive familiale şi comunitare, conferindu-i însă o semnificaţie şi o realitate complet noi ${ }^{52}$.

În descrierea făcută Cinei celei de Taină, Sfinţii Evanghelişti prezintă cele şapte acte săvârşite de către Mântuitorul ca alcătuind un tot unitar, căci El: (I) a luat (II) a binecuvântat (III) a frânt şi (IV) a dat, zicând: Luaţi mâncaţi, acesta este Trupul Meu (Mt. 26, 26-27), iar mai apoi, (V) a luat paharul, (VI) a mulţumit şi (VII) 1-a dat ucenicilor Săi, zicând: Beţi dintru acesta toți, acesta este Sângele meu, al Legii celei noi, care pentru mulţi se varsă spre iertarea păcatelor (Mt. 26, 28; Mc. 14, 24; Lc. 22, 20; I Cor. 11, 25). Toate aceste acte şi cuvinte au fost preluate de tradiţia liturgică primară şi transpuse în practică, în patru mari acte cultice:(I) aducerea pâinii şi a vinului, (II) binecuvântarea, adică sfinţirea lor, (III) frângerea pâinii şi (IV) împărtăşirea credincioșilor $^{53}$.

Actele săvârşite şi cuvintele rostite de către Mântuitorul s-au păstrat în Tradiţia vie a Bisericii, fiind modelul după care s-au săvârşit primele Liturghii creştine, pentru ca abia mai târziu, începând cu mijlocul secolului I, ele să fie aşternute în scris de către Sfinţ̧ii Evanghelişti. Descrierea instituirii Sfintei Euharistii din Noul Testament are un pronunţat caracter liturgic, şi a devenit ulterior normativă, influenţând naraţiunea cuvintelor de instituire din toate textele euharistice de mai târziu ${ }^{54}$.

Cuvintele de instituire apar în acea secţiune a anaforalei euharistice în care, după modelul euhologic al binecuvântării după cină (birkat ha-mazon), putea fi inserat un embolism narativ festal. Louis Ligier a arătat că această naraţiune a fost introdusă, fie în contextul mulţumirii pentru întreaga iconomie a mântuirii, fie în secţiunea finală

\footnotetext{
52 Pr. Prof. Dr. Vintilescu, Petre, Incercări de istorie a Liturghiei. Liturghia creştină în primele trei veacuri, Bucureşti, 1930, p. 18.

${ }^{53}$ Gregory Dix, The Shape of Liturgy, London, 1945, p. 48-49.

${ }^{54}$ J. Jeremias, Die Abendsmahlworte Jesu, Göttingen, 1967, p. 100-102.
} 
de cerere, adică în dipticele de mai târziu, ceea ce justifică şi poziţiile diferite pe care ea le poate avea în textele euhologice cunoscute până în prezent ${ }^{55}$.

Păstrate în tradiţia orală a Bisericii, cuvintele de instituire au fost folosite dintru început în cult, chiar dacă prima menţionare explicită a lor într-o anafora euharistică poate fi întâlnită abia în prima jumătate a secolului al III-lea în Tradiţia apostolică a Sfântului Ipolit Romanul. Referiri însă la uzul lor liturgic şi catehetic pot fi găsite în operele unor părinţi bisericeşti precum Origen ${ }^{56}$, Eusebiu al Cezareiii ${ }^{57}$ şi a Sfântului Vasile cel Mare ${ }^{58}$.

Secţiunea din anaforalele euharistice, atribuite marelui părinte capadocian care menţionează aceste cuvinte ale Mântuitorului rostite la Cina cea de taină, este una complexă, căci niciunul dintre aceste texte cultice nu reproduce fidel pasajele biblice, ci conţine elemente preluate din toate relatările scripturistice, la care a fost adăugat şi material euhologic nou.

Analizând naraţiunea cuvintelor de instituire din 76 de anaforale euharistice, Paul Cagin a ajuns la concluzia că au existat trei etape în dezvoltarea acestei importante secţiuni a canonului euharistic:

1. Într-o primă etapă, naraţiunea cuvintelor de instituire folosită în anafora a cunoscut o diversitate şi o amplificare datorită oralităţii cultului. Aşternerea ei în scris, în textul inspirat al Scripturii, a dus la o uniformizare şi precizare a conţinutului ei.

2. Într-o a doua etapă, în anaforalele euharistice apar relatări biblice combinate ale cuvintelor de instituire pentru a da naştere unei forme

${ }^{55}$ L. Ligier, Autour du sacrifice echaristique. Anaphores orientales et anamnese juive de Kippur, Nouvelle revue théologique 82, 1960, p. 40-55.

${ }^{56}$ Origen, Omilia la proorocul Ieremia 12,2 la E. Klostermann (ed.), Origenes Werke (=Die griechischen christlichen Schriftsteller 6), Leipzig, 1901, p. 87

57 Eusebiu de Cezareea, Demonstratio evangelica, 8,1 la I.A. Heikel (ed.), Eusebius Werke (=Die griechischen christlichen Schriftsteller 23), Leipzig, 1913, p. 366.

${ }^{58}$ Despre Botez 1,3,2, PG 31, 1576AB. 
armonioase de expunere. Cagin a văzut acest lucru ca pe un proces paralel producerii Diatessaron-ului lui Tatian.

3. Într-o ultimă etapă, a fost adăugat şi materialul ne-biblic ${ }^{59}$.

Cagin ar fi putut să adauge încă o etapă în plus, între cea de-a doua şi a treia de mai sus, şi anume tendinţa de a corecta o formă armonizată pentru a o face să coincidă cu una sau mai multe dintre relatările biblice $^{60}$.

După 16 ani de la apariţia operei lui Cagin, Fritz Hamm a publicat un vast studiu în care a aprofundat istoria textului cuvintelor de instituire. Autorul s-a ocupat de liturghiile din Alexandria, Ierusalim, Capadocia, Constantinopol şi Roma, şi chiar dacă metoda lui de aranjare a textului este mai puţin clară decât a lui Cagin, totuşi, în analiza sa, el a atras atenţia asupra gradului de complexitate a textului cuvintelor de instituire şi a ajuns la aceeaşi concluzie ca şi Cagin, demonstrând că redactarea cea mai apropiată de textul Scripturii nu este cea mai veche, ci, dimpotrivă, este rezultatul unui proces de uniformizare ${ }^{61}$.

Naraţiunea cuvintelor de instituire este una dintre cele mai complexe secţiuni ale anaforalei euharistice. Originea ei e legată de începuturile cultului creştin, iar evoluția ei a fost un amplu şi îndelungat proces. Cuvintele rostite de către Mântuitorul şi actele săvârşite la Cina cea de Taină s-au păstrat în Tradiţia orală a Bisericii primare pentru ca mai apoi să fie aşternute în scris în textul Sfintei Scripturi. Faptul că din tradiţia vie a Bisericii au fost preluate relatările instituirii Sfintei Euharistii este făcut evident şi prin diferenţa mare existentă între pasajele biblice între ele, căci textele Sfinţilor Matei şi

${ }^{59} \mathrm{P}$. Cagin, L'euchologue latine étudiée dans la tradition de ses formules et de ses formulaires. L'eucharistie, canon primitif de la messe ou formulaire essentiel et premier de toutes les liturgies (=Scriptorium Solesmense II), Paris, p. 246

${ }^{60}$ F.W. Fenwick, The Anaphoras of St. Basil and St. James: An Investigation into their Common Origin (=OCA 240), Roma, 1992, p. 132.

${ }^{61}$ A. Raes, L'étude de la liturgie syrienne: son état actuel, Miscellanea liturgica in honorem Cuniberti Mohlberg, Roma, 1948, p. 337. 
Marcu se bazează pe o anumită tradiţie orală, iar cele ale Sfinţilor Luca şi Pavel, pe o tradiţie orală distinctă.

Odată cu aşternerea în scris a Sfintei Scripturi, naraţiunea cuvintelor de instituire din anaforaua euharistică a fost mereu ajustată şi adaptată textelor biblice şi, în acelaşi timp, ea fost îmbogăţită cu material ne-biblic, fapt care a dus la conturarea unei anumite simetrii între actele binecuvântării pâinii şi cele ale sfinţ̧irii vinului.

d. ANAMNEZA ( $\dot{\alpha} v \alpha \dot{\alpha} \mu \nu \eta \iota \varsigma, \dot{\eta}=$ amintire, pomenire). Săvârşirea Sfintei Liturghii poate fi socotită un răspuns al Bisericii la îndemnul făcut de către Mântuitorul la Cina cea de Taină: „Faceţi aceasta spre pomenirea Mea" (I Cor. 11, 24; Lc. 22,19), iar anamneza cultică, sau zikkaron, cum apare în tradiţia cultică iudaică, nu este o simplă amintire sau rememorare psihologică, ci este actul prin care trecutul, prezentul şi viitorul devin un prezent continuu în celebrarea cultică. Actul memorial în sens biblic este astfel simultan comemorare, prezenţă şi anticipare. El concentrează, din iniţiativa divină, lucrarea mântuitoare şi revelatoare a Dumnezeului celui viu şi personal, angajat efectiv în istorie, în tripla ei dimensiune: trecută, prezentă şi viitoare. Memorialul, anamneza, face prezent nu doar trecutul, cât mai ales viitorul, de unde şi porunca expresă a Mântuitorului la Cina cea de Taină: "Aceasta să o faceţi spre pomenirea Mea" (Lc. 22, 19). În Iisus Hristos istoria se întâlneşte cu veşnicia, putând fi mereu actualizată, împlinind astfel viitorul.

Porunca anamnezei făcută de către Mântuitorul nu trebuie interpretată din premise elenistice - afirmă Joachim Jeremias -, ci palestiniene, semitice, în care subiectul oricărui act cultic este Dumnezeu, astfel încât expresia: „spre pomenirea Mea“ nu înseamnă în primul rând ca omul să pomenească ce a făcut Mântuitorul, ci, cu cea mai mare probabilitate, ca Dumnezeu Tatăl să Îşi aducă aminte de Hristos şi de ucenicii Săi, şi astfel porunca anamnezei nu este o invitaţie ca ucenicii să păzească amintirea lui Iisus (,repetaţi frângerea pâinii, ca să nu uitaţi de Mine"), ci o indicaţie eshatologic-orientală: „adunaţi-vă în continuare în ritul mesei ca şi comunitate nouă, ca în 
acest fel Dumnezeu să fie zilnic implorat să ducă la împlinire iconomia mântuitoare în Biserică" ${ }^{\prime 2}$.

Dumnezeu „Îşi aduce aminte” de Hristos, cel răstignit, Înviat şi Înălţat, întrucât trimite neîncetat pe Sfântul Duh, ca să Îl facă prezent pnevmatic până la cea de a doua Sa venire. Dumnezeu Tatăl este rugat de către întreaga comunitate euharistică, de către întreg Trupul lui Hristos, ca „pomenind” jertfa Mântuitorului să împlinească promisiunile adresate profeţilor, făcând prezentă în lumea aceasta Împărăţia viitoare, prin trimiterea Sfântului Duh. Astfel, pornind de la anamneza tuturor actelor iconomiei mântuirii, comunitatea poate îndrăzni să ceară lui Dumnezeu Tatăl venirea Mângâietorului pentru împlinirea finalităţii ultime a acestor acte: venirea în lumea aceasta a eshatonului prin permanentizarea prezenţei lui Hristos în celebrarea euharistică.

Anamneza ca parte a anaforalei euharistice. În textul anaforalei euharistice, după relatarea despre instituirea Jertfei, urmează imediat menţionarea a ceea ce Biserica face pentru pomenirea sau amintirea a tot ceea ce Iisus Hristos a făcut pentru mântuirea lumii.

Originile acestei secţiuni a anaforalei euharistice sunt legate de prezenţa în textul euharistic a naraţiunii cuvintelor de instituire cu care ea alcătuieşte o unitate, căci anamneza apare ca un răspuns la porunca Mântuitorul de la Cina cea de Taină: ,aceasta să o faceţi întru pomenirea Mea" (Lc. 22, 19 şi I Cor. 11, 24-25), fiind o mărturisire a ceea ce face în mod concret Biserica pentru a putea cere venirea Sfântului Duh şi împlinirea Împărăţiei viitoare. În toate anaforalele euharistice, anamneza este secţiunea care face trecerea de la naraţiunea cuvintelor de instituire la epicleză, şi are rolul unei concluzii finale la mulţumirea adusă în Rugăciunea hristologică pentru împlinirea întregii iconomii a mântuirii ${ }^{63}$.

Două tipuri distincte de anamneză pot fi identificate în ansamblul de texte euharistice cunoscute până în prezent. Primul tip are

62 J. Jeremias, Die Abendmahlworte Jesu, vierte, durchgesehene Auflage, Göttingen, 1967, p. 244.

${ }^{63}$ Pr. Prof. Dr. Vintilescu, Petre, Liturghierul explicat, Bucureşti, 1998, p. 247. 
ca element central menţionarea, într-o formă participială a substantivului d́vó $\mu v \eta \sigma ı \varsigma$ din Lc. 22, 19 şi I Cor. 11, 24-25, a termenului $\mu \varepsilon \mu \nu \eta \mu \varepsilon ́ v o r / m e m o r e s ~(a d u c a ̂ n d u-n e ~ a m i n t e)$. Din această categorie fac parte anaforaua Tradiţiei apostolice, cea din Constituţiile apostolice, cea a Sfântului Vasile cel Mare, cea a Sfântului Ioan Gură de Aur şi cea a Sfầntului Iacob ${ }^{64}$.

Cel de al doilea tip, ce poate fi întâlnit doar în anaforalele egiptene, reia terminologia paulină din I Cor. 11, 24-25, exprimând

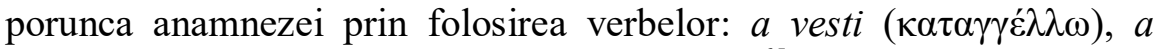

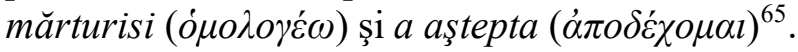

e. EPICLEZA ( $\dot{\pi} \pi i \kappa \lambda \eta \sigma \iota \varsigma, \dot{\eta}-$ epiklisis = invocare). Substantivul grec

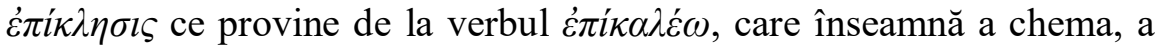
invoca, este termenul uzual folosit în cult pentru a desemna o rugăciune în care Sfântul Duh este invocat pentru a veni şi a sfinţi materia Sfintelor Taine şi pe credincioşi. În mod particular, epicleza a devenit termenul consacrat pentru acea secţiune a anaforalei euharistice în care preotul cere lui Dumnezeu Tatăl să trimită Duhul Sfânt asupra credincioşilor şi asupra Darurilor pentru a le sfinţi şi a le transforma în Trupul şi Sângele Mântuitorului Iisus Hristos.

Originea epiclezei poate fi găsită în schema euhologică iudaică: binecuvântare - mulţumire - cerere, ce a fost preluată şi reformulată în cultul creştin, devenind astfel structura de bază a oricărui text euharistic. Secţiunea a treia de cerere (Rahem = ai milă, Doamne) a binecuvântării după cină (birkat ha mazon) a fost modelul originar preluat din cultul iudaic după care în Liturghia apostolică erau formulate cererile comunităţii, care culminau printr-o invocare de venire a Mântuitorului. O astfel de epicleză simplă a fost expresia „Maranatha” din Didahia 10, 56 , ce are sensul imperativ de: „Vino, Doamne!", sau repetata chemare a Numelui Mântuitorului şi a

\footnotetext{
${ }^{64}$ Anton Hänggi, Irmgard Pahl (eds), Prex Eucharistica..., p. 81.

${ }^{65}$ Ibidem, p. 112.

66 Ibidem, p. 66.
} 
Sfântului Duh, aşa cum apare în Actele apocrife ale lui Toma scrise în jurul anului 200 în Siria ${ }^{67}$.

Sfầntul Iustin Martirul şi Filosoful vorbeşte în Apologia I, 66, 2 de pâinea ce a fost sfinţită „,prin cuvântul rugăciunii, care este de la El"68. Marele apologet subliniază astfel faptul că transformarea elementelor euharistice avea loc în urma unei rugăciuni care era rostită în conformitate cu modelul oferit de către Mântuitorul la Cina cea de Taină.

O primă mărturie certă a unei epicleze euharistice poate fi găsită în Tradiţia apostolică a Sfântului Ipolit, în care Sfântul Duh este invocat asupra darurilor şi asupra credincioşilor, fără însă a se preciza în mod expres cererea de transformare a pâinii şi vinului în Trupul şi Sângele Mântuitorului, cum o vor face epiclezele euharistice de mai târziu: ,Şi ne rugăm să trimiți Duhul Tău cel Sfânt peste darurile sfintei Tale Biserici; adunându-o pe ea într-unul, dă celor care participă la sfintele (Tale Taine) de a se împărtăşi, spre umplere de Duhul Sfânt, pentru întărirea credinţei lor în adevăr" [Et petimus ut mittas Spiritum tuum sanctum in oblationem sanctae ecclesiae; in unum congregans, des omnibus qui percepiunt de sanctis in repletionem Spiritus sancti, ad confirmationem fidei in veritate...." ${ }^{69}$.

În primele trei secole, în condiţiile în care terminologia trinitară nu fusese încă precizată, pentru prefacerea darurilor era invocat şi Logosul divin, aşa cum este cazul anaforalei lui Serapion din Thmuis: „Dumnezeule al adevărului, să vină Cuvântul Tău cel Sfânt asupra pâinii acesteia, pentru ca pâinea să se facă Trupul Cuvântului, şi asupra potirului acestuia, ca să devină Sângele adevărului”, ${ }^{\prime 70}$.

Abia din secolul patru începând, odată cu definiţiile dogmatice ale primelor sinoade ecumenice, epicleza a atins forma ei definitivă, în care rolul sfinţitor era atribuit în exclusivitate Persoanei Sfântului Duh, şi în

${ }^{67}$ Gabriele Winkler, Nochmals zu den Anfängen der Epiklese and des Sanctus im Eucharistischen Hochgebet, Theologische Quartalschrift 174, 1994, p. 216-220.

${ }^{68}$ Anton Hänggi, Irmgard Pahl (eds), Prex Eucharistica..., p. 70.

${ }^{69}$ Ibidem, p. 81.

${ }^{70}$ Ibidem, p. 130. 
care era menţionată şi cererea specială de prefacere a pâinii şi vinului în Trupul şi Sângele Mântuitorului. În acest sens, mărturia Sfầntului Chiril al Ierusalimului din Catehezele mistagogice (V, 7) este elocventă: „Apoi, sfinţindu-ne pe noi înşine prin aceste imnuri duhovniceşti, rugăm pe Dumnezeu cel iubitor de oameni să trimită Duhul Său cel Sfânt peste darurile puse înainte, pentru ca să prefacă pâinea în Trupul lui Hristos şi vinul în Sângele lui Hristos"71.

Evoluţia anaforalei a fost un amplu proces, ce a fãcut ca această secţiune atât de importantă a textului euharistic să apară în poziţii diferite în Liturghiile Răsăritului Ortodox. Astfel, în tradiţia alexandrină, epicleza urmează după Trisaghionul biblic în contextul laudei aduse Creatorului a toate. Ideea umplerii de slavă a toate prin venirea Mântuitorului în lume este în anaforaua Sfântului Marcu punctul de plecare şi premisa cererii pentru ca şi darurile puse înainte să se umple de binecuvântare prin venirea Sfântului Duh ${ }^{72}$. În tradiţia est-siriană, epicleza apare la sfârşitul anaforalei, fiind strâns legată de doxologia finală ${ }^{73}$, iar în cea vest-siriană, ea alcătuieşte un tot unitar alături de cuvintele de instituire şi anamneză ${ }^{74}$.

În opinia lui Robert Taft, sensul evoluţiei epiclezei a fost de la „invocarea Logosului la cea a Sfântului Duh”75, însă Gabriele Winkler a nuanţat acest punct de vedere arătând că epicleza a evoluat de la invocarea Numelui Mântuitorului sau a Sfântului Duh la cererea concretă de trimitere a Mângâietorului asupra darurilor. Cercetătoarea de la Tübingen a făcut distincţia între două tipuri fundamentale de anaforale euharistice, unul sirian - epicletic, şi altul grec - hristocent-

${ }^{71}$ Cyrille de Jérusalem, Catéchèses mystagogiques, ed. A. Piédagnel (=SC 16 bis), Paris, 1966, p. 154-155.

${ }^{72}$ Anton Hänggi, Irmgard Pahl (eds), Prex Eucharistica..., p. 112.

${ }^{73}$ Ibidem, p. 374-410.

${ }^{74}$ Ibidem, p. 204-373.

75 R.Taft, Ecumenical Scholarship and the Catholic-Orthodox Epiclesis Dispute, Ostkirchliche Studien 45, 1996, p. 201-226; Idem, From logos to spirit: On the early history of the epiclesis, A. Heinz, şi H. Rennings (eds.), Gratias agamus. Studien zum eucharistischen Hochgebet. Festschrift Balthasar Fischer, Freiburg / Basel / Wien, 1992, p. 489-502. 
ric: în primul dintre ele, prin imperativul „vino!”, Sfântul Duhul este invocat să coboare asupra comunităţii, iar într-o evoluţie ulterioară, şi asupra darurilor, pe când în cel de al doilea tip, în epicleza ce este strâns legată de cuvintele de instituire şi de anamneză, este cerută trimiterea Sfântului Duh de către Tatăl sau Fiul asupra darurilor ${ }^{76}$.

Diferenţa aceasta fundamentală între cele două tipuri de epicleză fusese remarcată încă din 1972 de către Sebastian Brock, care a demonstrat că cele mai vechi texte euharistice folosesc verbul „,a veni” pentru a invoca venirea Mântuitorului sau a Sfầntului Duh, pe când în anaforalele mai evoluate ale secolului $\mathrm{V}$, verbul dominant este „a trimite”, căci Tatăl sau Însuşi Mântuitorul Iisus Hristos este rugat să trimită Duhul Sfânt asupra credincioşilor şi asupra darurilor ${ }^{77}$.

f. DIPTICELE ( $\delta i \pi \tau v \xi$ - diptix şi $\delta i \pi \tau v \chi o \varsigma ~-~ d i p t i h o s=$ pliat în două, în două părţi) reprezentă două coperţi de lemn, legate cu balamale şi care se pot închide ca o carte. Pe părţile interioare ale acestor coperţi se zugrăvesc icoane sau se înscriu pomelnicele cu vii şi morţi pentru care preotul se roagă la Sf. Liturghie, după ce a terminat marea rugăciune a Sfintei Jertfe (anaforaua). Această rugăciune de mijlocire generală, pentru vii şi morţi, pe care preotul o face după epicleză (rugăciunea Sfintei Jertfe) poartă denumirea de diptice (de la faptul că numele celor pentru care se roagă sunt înscrise în aceste registre, sub formă de coperţi care se închid).

Denumirea de „diptice" dată acestei ultime părţi a anaforalei euharistice se datorează unei vechi practici liturgice de a fi pomenite în rugăciunea de mijlocire de după prefacerea darurilor numele credincioşilor, atât a celor vii, cât şi a celor adormiţi, ai unei anumite comunităţi. Aceste pomeniri erau făcute pe baza unor liste cu nume ce

\footnotetext{
${ }^{76}$ Gabriele Winkler, Nochmals zu den Anfängen der Epiklese and des Sanctus im Eucharistischen Hochgebet, Theologische Quartalschrift 174, 1994, p. 216-220.

77 S. Brock, The Epiklesis in the Antiochene Baptismal Ordines: Symposion Syriacum 1972, célébré dans les fours 26-31 octobre 1972 à 1' Institut Pontifical Oriental de Rome. Rapports et Communications (=OCP 197), Roma, 1974, p. 210-211.
} 
luau forma unor carnete, care erau alcătuite din două coperte de aur, de argint sau de alt metal, şi care erau unite între ele pentru a se putea închide una peste alta. Pe feţele lor erau scrise numele ce trebuiau pomenite, atât ale celor vii, cât şi ale celor adormiţi. Când însă şirul numelor de pomenit era prea lung, se adăugau între cele două coperte încă una, două, trei sau mai multe foi de pergament sau de papirus, obţinându-se astfel adevărate caiete sau cărţi. De la această conformaţie ele au primit denumirea de diptice ${ }^{78}$.

Pomenirea numelor putea fi făcută în diferite momente ale Sfintei Liturghii, fie în ectenii, fie în rânduiala proscomidiei, fie în cadrul anaforalei euharistice. Robert Taft a demonstrat faptul că în secolul IV au existat două tradiţii distincte de pomenire a numelor în Sfânta Liturghie. Prima dintre ele, specifică Ciliciei şi Mesopotamiei, asocia dipticele cu momentul aducerii darurilor pentru Sfânta Euharistie, când erau reţinute numele, atât ale celor care aduceau, cât şi ale celor pentru care erau aduse prescurile pentru a fi mai apoi citite de către diaconi chiar înainte de începutul anaforalei euharistice. În cea de a doua tradiţie, ce caracteriza restul teritoriilor Răsăritului ortodox, pomenirea numelor a fost inserată în cererile de după epicleza euharistică. Această tradiţie s-a extins cu timpul şi s-a impus chiar şi în regiunile în care la origini dipticele erau citite înainte de anafora, exceptând acele teritorii care nu au fost în zona de influenţă a Bizanţului ${ }^{79}$.

Prin urmare, în această parte a anaforalei, ce este definită prin termenul consacrat de ,diptice”, două elemente pot fi distincte: pe de o parte, cererile ce urmează epiclezei euharistice, iar pe de altă parte, dipticele propriu-zise, adică pomenirea pe nume, atât a celor adormiţi, cât şi a celor vii, ce a fost inserată în această rugăciunea de cerere de după prefacerea darurilor. Când şi cum s-a petrecut această adăugare a

\footnotetext{
${ }^{78}$ Pr. Prof. Dr. Petre Vintilescu, Liturghierul explicat, Bucureşti, 1998, p. 273.

${ }^{79}$ Robert Taft, The Great Entrance. A History of the Transfer of Gifts and Other Preanaphoral Rites of the Liturgy of St. John Chrysostom (=OCA 200), Roma, 1978, p. 48-49, 58-59; Idem, A History of the Liturgy of St. John Chrysostom, Volume IV: The Diptychs, Roma, 1991, p. 27.
} 
pomenirii numelor în anaforaua euharistică nu poate fi precizat cu siguranţă.

Istoria evoluţiei Liturghiei indică faptul că şi după mutarea proscomidiei la începutul sinaxei euharistice (secolele V-VI) pomenirile numelor cu voce tare asociate acestui ritual au fost în continuare făcute în unele tradiţii liturgice precum cea est-siriană şi cea maronită tot înainte de începutul anaforalei, adică în locul ocupat iniţial de rânduiala proscomidiei, pe când în alte tradiţii, precum cea bizantină, antiohiană şi ierusalimiteană, ele au fost inserate în canonul euharistic, în rugăciunea de după epicleză, mai precis au fost ,atrase” de către cererile pentru diversele categorii de credincioşi rostite după prefacerea darurilor.

Analiza vechilor texte euharistice precum: Didahia 10, $5^{80}$, Euhologionul lui Serapion de Thmuis ${ }^{81}$, Constituţiile Apostolice VIII, 12, 40-49 ${ }^{82}$, Testamentum Domini I, $23^{83}$, anaforaua Sfinţilor Apostoli Addai şi Mari ${ }^{84}$, şi papirusurile Strasbourg Gr. $254^{85}$, John Rylands $465^{86}$ şi Der Balizeh ${ }^{87}$ indică faptul că rugăciunea de cerere de după prefacerea darurilor a fost dintru început o parte integrantă a canonului euharistic, originea ei putând fi găsită în secţiunea a treia de cerere (Rahem = ai milă, Doamne) a binecuvântării după cină (birkat ha mazon) ce completa schema euhologică iudaică: binecuvântare mulţumire - cerere, ce a fost mai apoi preluată şi transpusă în cultul creştin. Pe acest element străvechi a putut fi „grefată” pomenirea numelor, care nu a avut un loc stabil, fiind adesea asociată, fie ecteniilor de la începutul Liturghiei, fie ecteniilor pentru cei

\footnotetext{
${ }^{80}$ W. Rordorf, A. Tuilier p. 180.

${ }^{81}$ Anton Hänggi, Irmgard Pahl (eds), Prex Eucharistica..., p. 132.

${ }^{82}$ Ibidem, p. 92-94.

${ }^{83}$ Ibidem, p. 221.

${ }^{84}$ Ibidem, p. $378-380$.

${ }^{85}$ Ibidem, p. 117.

${ }^{86}$ Ibidem, p. 123.

${ }^{87}$ Ibidem, p. 125.
} 
credincioşi, fie înainte de începutul anaforalei euharistice, fie la sfârşitul ei, la cererile de după epicleză ${ }^{88}$.

Prima menţionare a dipticelor în sensul propriu al cuvântului, de citire a numelor, o face Teodor de Mopsuestia în Omilia $15,43^{89}$, în care aminteşte de pomenirea pe nume a viilor şi a morţilor de către diacon inainte de anaforaua euharistică, pentru ca în Omilia 16, 14 el să vorbească şi despre cererile pe care preotul le face după epicleză.

Introducerea rostirii numelor celor vii şi a celor adormiţi în anaforaua euharistică a operat o grupare şi totodată o structurare în jurul acestor pomeniri a cererilor rostite de către preot după epicleză, de aşa manieră încât această întreagă secţiune de cereri a fost împărţită în două mari părţi, şi anume, una consacrată pomenirii celor vii, şi alta dedicată pomenirii celor adormiţi. Succesiunea celor două părţi este diferită în diversele tradiţii liturgice răsăritene, astfel în cea egipteană, palestiniană şi cea est-siriană pomenirea celor vii precede pe cea a celor adormiţ̧i, urmând imediat după epicleză, ca o directă continuare a cererilor exprimate după invocarea Sfântului Duh asupra credincioşilor şi asupra darurilor, pe când în tradiţia bizantină şi în cea armeană, dipticele pentru cei adormiţi au fost asimilate pomenirii sfinţilor şi au fost plasate înaintea dipticelor pentru cei vii.

Dipticele pentru cei vii au fost la început simple pomeniri ale membrilor unei comunităţii şi erau variabile, cuprinzând numele celor care aduceau şi ale celor pentru care erau aduse darurile. $\mathrm{Cu}$ timpul însă, odată cu evoluţia Bisericii, pomenirile pentru cei vii au devenit oficiale, menţionând şi pe toţi membrii ierarhiei Bisericii locale, ajungând astfel să fie o expresie a comuniunii intereclesiale. Robert Taft este de părere că dipticele simple, parohiale şi spontane ale comunităţii au coexistat un timp cu cele ierarhice şi oficiale, dar au fost treptat înlocuite cu totul de acestea din urmă ${ }^{90}$.

${ }^{88}$ R. Taft, A History of the Liturgy of St. John Chrysostom, Volume IV: The Diptychs..., p. 27.

89 R. Tonneau, R. Devreesse, Les homelies catechetiques de Theodore de Mopsueste (= Studi e testi 145) Vatican, 1949, p. 528.

${ }^{90} \mathrm{R}$. Taft, A History of ..., p. 59. 
Dipticele pentru cei adormiţi au cunoscut şi ele o evoluţie asemănătoare de la simplitate spre diversitate. La început, ele au fost doar simple comemorări ale creştinilor adormiţi ai unei comunităţi, pentru ca mai apoi ele să fie extinse şi să ajungă să cuprindă întreaga succesiune apostolică a Bisericii locale. Pomenirii celor adormiţi i-a fost asociată şi menţionarea sfinţilor care iniţial a fost un element separat al textului euharistic, iar această fuziune a dus ca în ritul bizantin şi armean dipticele pentru cei morţi să premeargă pe cele pentru cei vii, ajungându-se astfel să fie menţionată în cererile după prefacerea darurilor întreaga Biserică, atât cea triumfătoare, cât şi cea luptătoare.

Pomenirea numelor celor adormiţi era făcută la început de către diacon cu voce tare, după rostirea ecfonisului: „Mai ales pe/cu Preasfânta, Curata, Preabinecuvântata Fecioara Maria...", iar numele celor vii erau rostite tot cu voce tare, tot de către diacon, după un alt ecfonis al preotului: „Întâi pomeneşte, Doamne...”. Din secolul al XIlea, numele, atât ale celor vii, cât şi ale celor adormiţi, nu au mai fost pomenite cu voce tare de către diacon, ci au ajuns să fie rostite cu voce joasă şi să fie tot mai mult asimilate cererilor ce erau spuse în taină de către preot sau episcop pentru aceste categorii de credincioşi, ajungându-se la situaţia ca în anaforalele euharistice aflate astăzi în uz să nu mai existe diptice decât cu numele ${ }^{91}$.

\section{Concluzii}

1. Succinta analiză făcută acestor termeni folosiţi în cultul Bisericii a fost în măsură să scoată în evidenţă bogăţia şi varietatea de sensuri pe care limbajul liturgic le cuprinde, şi cât de importantă este cateheza în lucrarea pastoral misionară a Bisericii.

2. Pentru înţelegerea şi receptarea adecvată a acestor termeni, este evidentă nevoia de aprofundare a modului în care termenii uzuali din cult au apărut şi evoluat în decursul vremii, şi mai ales, a modului în care au fost interpretaţi şi analizaţi în tradiţia vie a Bisericii.

${ }^{91}$ Gabriele Winkler, Interzessionen, II, p. 345-351. 
3. Contextul religios, cultural, social şi istoric actual cere imperios ca Ortodoxia să fie relevantă în primul rând pentru tineri pentru a ajunge astfel fermentul din mijlocul lumii care ,să dospească toată frământătura”. Provocările modernităţii sunt majore şi se răsfrâng pe toate palierele vieţii şi în toate domeniile de activitate. Ele cer o renaştere a Catehezei ortodoxe, singura care poate da răspunsurile ultime la problemele majore cu care se confruntă societatea modernă consumistă. De aceea, discursul nostru teologic trebuie să aleagă calea înnoirii patristice şi liturgice, trăind din duhul Tradiţiei apostolice şi explicându-l într-un mod adaptat cerinţelor vremii. Influenţa secularismului în educaţia tinerilor, arătată în negarea tuturor valorilor societăţii tradiţionale româneşti, poate fi estompată doar prin grija pastorală a preoţilor şi prin adoptarea unui nou tip de limbaj viu, personal şi relevant pentru omul contemporan.

4. În lumea actuală, marcată de pluralismul şi democraţia egoismului şi a afirmării umanismului, Bisericii îi revine o sarcină misionară dificilă: dacă Sfânta Liturghie devine sursa a toată teologhisirea, atunci răspunsul Bisericii la toate problemele modernităţii va fi unul viu, profund, personal şi relevant. Discursul teologic care nu are ca izvor Liturghia şi nu are imprimată în el experienţa personală ca rodire a vorbirii cu Dumnezeu, riscă extremele scolasticismului (dogmatic), ale ritualismului (liturgic), sau ale formalismului (etic). Criza profundă a tinerilor din societatea modernă poate fi depăşită doar printr-o revigorare a Teologiei prin orientarea şi centrarea ei pe viaţa liturgică a Bisericii. Doar astfel discursul teologic modern poate deveni unul pastoral, mistic şi relevant pentru omul secolului XXI.

\section{Bibliografie}

\section{Izvoare}

1. Basilius Caesariensis, Asceticon magnum sive Quaestiones (regulae brevius tractatae), PG 31, 1236BC.

2. Basilius Caesariensis, Enarratio in prophetam Isaiam, PG 30, $165 \mathrm{~B}$. pretiosae crucis, PG 52, 838BC.

3. C. van Beek (ed.), Passio ss Perpetuae et Felicitatis, Nijmegen, 1936.

4. Cyrille de Jérusalem, Catéchèses mystagogiques, ed. A. Piédagnel (=SC 16 bis), Paris, 1966.

5. Cyrille de Jérusalem, Catéchèses mystagogiques, ed. A. Piédagnel (=SC 16 bis), Paris, 1966.

6. Cyrillus Alexandrinus, Epistulae paschales sive Homiliae paschales (epist. 1-30), , PG 77, 864BC.

7. E. Dekkers (ed.), Tertulliani Opera I (=CCSL I), Turnhout, 1954. 
8. Eusébe de Césarée, Histoire ecclésiastique, ed. G. Bardy (=SC 55), Paris, 1958.

9. Eusebiu de Cezareea, Demonstratio evangelica, 8,1 la I.A. Heikel (ed.), Eusebius Werke (=Die griechischen christlichen Schriftsteller 23), Leipzig, 1913.

10. Henry George E. Liddell, \& Robert Scott, A Greek-English Lexicon (revised ed.), Oxford: At Clarendon Press, 1996. Lampe, G.W.H., $A$ Patristic Greek Lexikon, Oxford: At the Clarendon Press, 2003.

11. Jaubert, A. Clément de Rome. Epitre aux Corinthiens (=SC 167), Paris, 1971.

12. Joannes Chrysostomus In epistulam ad Hebraeos (homiliae 1-34), PG $63,92 \mathrm{C}$.

13. Origen, Omilia la proorocul Ieremia 12,2 la E. Klostermann (ed.), Origenes Werke (=Die griechischen christlichen Schriftsteller 6), Leipzig, 1901.

14. Theoleptus Philadelphiensis, Orationes monasticae 4, critical edition by R.E. Sinkewicz in: Theoleptos of Philadelphia, The Monastic Discourses [Studies and Texts 111. Toronto: Pontifical Institute of Medieval Studies, 1992].

\section{Articole şi studii}

1. Bouley, A., From Freedom to Formula, Washington, D.C., 1981.

2. Bradshaw, Paul, The Homogenization of Christian Liturgy - Ancient and Modern: Presidential Address, Studia Liturgica 26, 1996.

3. Branişste, Pr. Ene, Explicarea Sfintei Liturghii după Nicolae Cabasila, Teza de doctorat, Bucureşti, 1943.

4. Idem, Liturgica specială, manual pentru Institutele Teologice, Bucureşti, 1980.

5. Brock, S., The Epiklesis in the Antiochene Baptismal Ordines: Symposion Syriacum 1972, célébré dans les fours 26-31 octobre 1972 à 1' Institut Pontifical Oriental de Rome. Rapports et Communications (=OCP 197), Roma, 1974.

6. Cabasila, Nicolae, Explicarea Sfintei Liturghii, PG 150, 368-492, traducere românească la Pr. Prof. Dr. Ene Branişte, Explicarea Sfintei Liturghii, Bucureşti, 1943.

7. Cagin, P., L'euchologue latine étudiée dans la tradition de ses formules et de ses formulaires. L'eucharistie, canon primitif de la messe ou formulaire essentiel et premier de toutes les liturgies (=Scriptorium Solesmense II), Paris. 
8. Davie, Grace, Religion in Britain Since 1945: Believing Without Belonging, Oxford, Basil Blackwell, 1994.

9. Dix, Gregory, The Shape of Liturgy, London, 1945.

10. Fenwick, F.W., The Anaphoras of St. Basil and St. James: An Investigation into their Common Origin (=OCA 240), Roma, 1992.

11. Florensky, Pr. Pavel, Slovesnie slujenie, în „Journal Moskovsckoi Patriarhii", nr. 4, 1977.

12. Gauchet, Marcel, Ieşirea din religie. Parcursul laicităţii, trad. de Mona Antohi, Bucureşti, Edit. Humanitas, 2006.

13. Hänggi, Anton, Pahl, Irmgard (eds), Prex Eucharistica, Fribourg, 1968.

14. Jeremias, J., Die Abendmahlworte Jesu, vierte, durchgesehene Auflage, Göttingen, 1967.

15. Kretschmar, G., Die frühe Geschichte Jerusalemer Liturgie, Jahrbuch für Liturgik und Hymnologie 2, 1956.

16. Lampe, G.W.H., A Patristic Greek Lexikon, Oxford: At the Calderon Press, 2003.

17. Ligier, L., Autour du sacrifice echaristique. Anaphores orientales et anamnese juive de Kippur, Nouvelle revue théologique 82, 1960.

18. Parenti, S. / Velkovska, E., L'Eucologio Barberini Gr. 336. Seconda editione riveduta. Con traduzione in lingua italiana (=BELS 80), Roma, 2000.

19. Probst, Ferdinand, Liturgie der drei ersten christlichen Jahrhunderte, Tübingen, 1870.

20. Raes, A., L'étude de la liturgie syrienne: son état actuel, Miscellanea liturgica in honorem Cuniberti Mohlberg, Roma, 1948.

21. Ratcliff, E. C., The Sanctus and the Pattern of the Early Anaphora, Journal of Ecclesiastical History 1, 1950.

22. Stăniloae, Pr. Dumitru, Spiritualitate şi comuniune în Liturghia ortodoxă, Craiova, 1986.

23. Taft, Robert The Great Entrance. A History of the Transfer of Gifts and Other Preanaphoral Rites of the Liturgy of St. John Chrysostom (=OCA 200), Roma, 1978. Idem, A History of the Liturgy of St. John Chrysostom, Volume IV: The Diptychs, Roma, 1991.

24. Idem, Ecumenical Scholarship and the Catholic-Orthodox Epiclesis Dispute, Ostkirchliche Studien 45, 1996.

25. Idem, From logos to spirit: On the early history of the epiclesis, A. Heinz, şi H. Rennings (eds.), Gratias agamus. Studien zum eucharistischen Hochgebet. Festschrift Balthasar Fischer, Freiburg / Basel / Wien, 1992. 
26. Idem, How Liturgies Grow: The Evolution of the Byzantine Divine Liturgy, Orientalia Christiana Periodica 43, 1977.

27. Idem, The Interpolation of the Sanctus into the Anaphora: When and Where? A Review of the Dossier, I, OCP 57, 1991.

28. Tonneau, R. R., Devreesse, Les homelies catechetiques de Theodore de Mopsueste (= Studi e testi 145) Vatican, 1949.

29. Vintilescu, Pr. Petre, Expresiunea ,slujba cuvântătoare” din Liturghierul român, Bucureşti, 1939.

30. Idem, Pr. Petre, Liturghierul explicat, Bucureşti, 1972, p. 227-276; Idem, Anaforaua sau ritul Sfintei Jertfe euharistice, în „Biserica Ortodoxă Română", nr. 7-8, 1961.

31. Idem, Pr. Prof. Dr. Petre, Incercări de istorie a Liturghiei. Liturghia creştină în primele trei veacuri, Bucureşti, 1930.

32. Idem, Pr. Prof. Dr. Petre, Liturghierul explicat, Bucureşti, 1998.

33. Winkler, Gabriele, Interzessionen, II.

34. Idem, Nochmals zu den Anfängen der Epiklese and des Sanctus im Eucharistischen Hochgebet, Theologische Quartalschrift 174, 1994.

35. Idem, Nochmals zu den Anfängen der Epiklese and des Sanctus im Eucharistischen Hochgebet, Theologische Quartalschrift 174, 1994. 